\title{
Rap1, Rif2, and the Ku complex work in concert to cap chromosome ends
}

Fernando R. Rosas Bringas ${ }^{1}$, Sonia Stinus ${ }^{1}$, Lisa Wanders ${ }^{1}$, Pien de Zoeten ${ }^{1}$, Marita Cohn $^{2}$, and Michael Chang ${ }^{1,3, *}$

${ }^{1}$ European Research Institute for the Biology of Ageing, University of Groningen, University Medical Center Groningen, Groningen, The Netherlands

${ }^{2}$ Department of Biology, Lund University, Lund, Sweden

${ }^{3}$ Lead contact

*Correspondence: m.chang@umcg.nl 


\section{Summary}

Rap1 is the main protein that binds double-stranded telomeric DNA in Saccharomyces cerevisiae. Rap1 can also bind and promote the formation of G-quadruplexes, which are thought to form at telomeres. Examination of the telomere functions of Rap1 is complicated by the fact that it also acts as a transcriptional regulator of hundreds of genes and is encoded by an essential gene. In this study, we disrupt Rap1 telomere association and G-quadruplex formation by expressing a mutant telomerase RNA subunit (tlc1-tm) that introduces mutant telomeric repeats. Remarkably, $t l c 1-t m$ cells grow as well as wild-type cells, although depletion of Rap1 at telomeres causes defects in telomere length regulation and telomere capping. We find that Rap1, Rif2, and the Ku complex work in parallel to prevent telomere degradation, and absence of all three causes lethality. The partially redundant mechanisms may explain the rapid evolution of telomere components in budding yeast species.

Keywords: Rap1, Rif2, Ku complex, telomere, telomerase, tlc1-tm, G-quadruplex, yeast 


\section{Introduction}

Telomeres, nucleoprotein complexes located at the ends of eukaryotic chromosomes, protect chromosome ends from degradation, from telomere-telomere fusion events, and from being recognized as double-stranded DNA breaks (Jain and Cooper, 2010). In most eukaryotic species, telomeric DNA consists of tandem G/C-rich repeats of double-stranded DNA with the G-rich strand extending to form a 3' single-stranded overhang. These repeats are bound by specialized proteins - some to the double-stranded region and others to the $3^{\prime}$ overhangwhich are important for proper telomere function. Telomere length is maintained by a dynamic process of shortening and lengthening. Telomeres shorten due to incomplete DNA replication and nucleolytic degradation, and are lengthened by the action of a specialized reverse transcriptase called telomerase (Jain and Cooper, 2010). At its core, telomerase consists of a catalytic protein subunit and an RNA subunit, and extends telomeres by iterative reverse transcription of a short G-rich sequence to the $3^{\prime}$ overhang, using the RNA subunit as a template.

Due to the G-rich nature of the telomeric repeats, telomeric DNA has the potential to form G-quadruplexes, which are highly stable secondary structures composed of Hoogsteen hydrogen-bonded guanines arranged in planar G-tetrads stacked together (Rhodes and Lipps, 2015). Intramolecular G-quadruplexes are predicted to form within sequences containing four runs of at least three guanines $\left(\mathrm{G}_{\geq 3} \mathrm{~N}_{\mathrm{x}} \mathrm{G} \geq 3 \mathrm{~N}_{\mathrm{x}} \mathrm{G} \geq 3 \mathrm{~N}_{\mathrm{x}} \mathrm{G} \geq 3\right)$, and the telomeres of most eukaryotic organisms conform to this consensus sequence. While most studies on G-quadruplexes have been carried out in vitro, there is also in vivo work supporting the existence of Gquadruplexes at telomeres. The most direct evidence comes from studies in ciliates. The telomere-binding protein TEBP $\beta$, from the related ciliates Oxytricha nova and Stylonychia lemnae, can promote the formation of G-quadruplexes in vitro (Fang and Cech, 1993; Paeschke et al., 2005). Knockdown of TEBP $\beta$ in S. lemnae eliminates detection of telomeric 
G-quadruplexes in vivo using a G-quadruplex-specific antibody (Paeschke et al., 2005).

Telomeric G-quadruplexes are not detected during S phase, presumably to allow replication of telomeres (Paeschke et al., 2005). Unfolding of telomeric G-quadruplexes during S phase requires phosphorylation of TEBP $\beta$, as well as telomerase and a RecQ-like helicase

(Paeschke et al., 2005; Paeschke et al., 2008; Postberg et al., 2012). Whether G-quadruplexes have an evolutionarily conserved function in telomere biology is still unknown (Bryan, 2020).

In the budding yeast Saccharomyces cerevisiae, the telomere binding protein Rap1, like TEBP $\beta$, can bind and promote the formation of G-quadruplexes in vitro (Giraldo and Rhodes, 1994; Traczyk et al., 2020). Rap1 is also the main double-stranded telomeric DNA binding protein (Buchman et al., 1988; Conrad et al., 1990), with important roles in regulating telomere length (Lustig et al., 1990; Conrad et al., 1990; Marcand et al., 1997), transcriptional silencing of subtelomeric genes (Kyrion et al., 1993), and preventing telomere-telomere fusions (Pardo and Marcand, 2005). Rap1 mediates these functions in part by recruiting additional proteins (i.e. Rif1, Rif2, Sir3, and Sir4) via its C-terminal domain (Hardy et al., 1992; Wotton and Shore, 1997; Moretti et al., 1994). Expression of a mutant Rap1 lacking the C-terminal domain, which retains the ability to bind telomeric sequences, mimics the deletion of the $R I F$ and SIR genes in terms of telomere length regulation and subtelomeric gene silencing (Wotton and Shore, 1997; Kyrion et al., 1993). However, the telomeric functions of Rap1 are not limited to the recruitment of Rif and Sir proteins. For example, although Rif2 and Sir4 are important for the inhibition of telomere end-to-end fusions, Rap1 also inhibits fusions independently of Rif2 and Sir4 (Marcand et al., 2008). In addition, binding of Rap1 to telomeric repeats is thought to promote replication fork pausing and breakage of dicentric chromosomes at telomere fusions independently of the Rif and Sir proteins (Makovets et al., 2004; Guérin et al., 2019). Despite the central role of Rap1 in yeast 
telomere biology, its study is complicated by the fact that Rap1 is also a transcription factor that regulates the expression of a few hundred genes (Lieb et al., 2001). Moreover, RAPl is essential for viability (Shore and Nasmyth, 1987), preventing analysis of a gene deletion mutant.

In this study, we examined the function of G-quadruplexes and Rap1 at S. cerevisiae telomeres by expressing a mutant telomerase RNA subunit (tlc1-tm) that introduces $\left[(\mathrm{TG})_{0}\right.$ ${ }_{4}$ TGG] ${ }_{n}$ ATTTGG mutant telomeric repeats instead of wild-type (TG)0-6TGGGTGTG(G) $0-1$ repeats (Chang et al., 2007; Förstemann and Lingner, 2001). The mutant repeats are impaired in the formation of G-quadruplexes. We find that Rap1 binds very poorly to mutant telomeric sequences. Despite being deficient in both G-quadruplex formation and Rap1 binding, tlc1-tm cells are viable and grow as well as wild-type cells. The depletion of Rap1, not surprisingly, causes telomere length homeostasis defects. Unexpectedly, the overall levels of Rif2 at telomeres are unaffected, and Rif2 is crucial for preventing $t l c 1$-tm telomeres from degradation by the MRX complex. The yeast Ku complex functions in parallel to protect tlcltm telomeres, and absence of both Rif2 and the Ku complex renders tlcl-tm cells inviable. Our findings reveal multiple redundant mechanisms that may have been important for the rapid evolution of telomere components in budding yeasts.

\section{Results}

\section{tlc1-tm mutant telomere sequences do not form G-quadruplexes}

To assess the role of G-quadruplexes at yeast telomeres, we require a yeast strain with telomeric DNA sequences that lack the potential to form G-quadruplexes. Such a strain can be obtained by mutating the template sequence of the RNA subunit of telomerase, TLC1. Ideally, this mutant would only affect G-quadruplex formation and no other aspects of telomere biology. The vast majority of mutations to the TLC1 template sequence cause 
disruption of telomerase enzymatic activity, and consequently, replicative senescence (Förstemann et al., 2003). Those that do not are often associated with slow growth, dramatic alterations in telomere profiles (i.e. elongated, very short, or extensively degraded), and aberrant chromosome separation and segregation (Förstemann et al., 2003; Lin et al., 2004). The $t l c 1-t m$ mutant introduces [(TG) ${ }_{0-4}$ TGG $]_{n}$ ATTTGG mutant telomeric repeats instead of wild-type $(\mathrm{TG})_{0-6}$ TGGGTGTG $(\mathrm{G})_{0-1}$ repeats, and grows as well as a wild-type strain (Chang et al., 2007; Förstemann and Lingner, 2001; Figure 1A). Telomeres in the tlc1-tm mutant are on average longer and more heterogeneous in length than in wild-type strains (Figure 1B), but the telomere profile of $t l c l-t m$ is much less dramatically altered compared to most other mutants of TLC1 with altered template sequences (Förstemann et al., 2003; Lin et al., 2004).

The lack of the GGG motif in the mutant repeat sequence should weaken the potential of G-quadruplex formation. To test this idea, we used the G-quadruplex prediction tool, G4Hunter, where a score greater than 1.2 indicates high G-quadruplex-forming potential (Brázda et al., 2019). While, analysis of wild-type sequences gave G4Hunter scores of 1.366, 1.375, and 1.286 (see sequences used in Figure 1C), none of the three analyzed mutant tlcltm sequences had a score greater than 1 (Figure 1C), thus indicating that the mutant telomeric sequences have reduced G-quadruplex-forming potential. To validate this hypothesis, we subjected oligonucleotides with either wild-type or $t l c 1-t m$ telomere sequences to circular dichroism (CD) analysis after incubation with potassium. In agreement with previous studies reporting that yeast telomeric DNA can fold into G-quadruplex structures in vitro (Venczel and Sen, 1993; Giraldo and Rhodes, 1994), we find that all three oligonucleotides composed of wild-type telomeric sequence generate a negative peak at $240 \mathrm{~nm}$ and a positive peak at $263 \mathrm{~nm}$ (Figure 1C), which is a pattern consistent with parallel G-quadruplex formation. In contrast, none of the oligonucleotides with $t l c 1$ - $t m$ telomere sequence form a pattern that is indicative of G-quadruplex formation (Figure 1C). 
There is evidence to suggest that stabilization of G-quadruplexes suppresses the temperature sensitivity of the capping-defective $c d c 13-1$ mutant (Smith et al., 2011). Cdc13 is a single-stranded telomeric DNA binding protein; the $c d c 13-1$ mutant loses the ability to block excessive nucleolytic resection of telomeric DNA at elevated temperatures, resulting in an accumulation of single-stranded telomeric DNA (Lin and Zakian, 1996; Nugent et al., 1996). The folding of this DNA into G-quadruplexes has been proposed to facilitate telomere capping by inhibiting further nucleolytic resection (Smith et al., 2011). To test whether $t l c 1$ tm telomere sequences are defective in forming G-quadruplexes in vivo, we stabilized Gquadruplexes in a $c d c 13-1$ mutant by deleting PIF1. Pif1 is a helicase and a potent unwinder of G-quadruplexes (Paeschke et al., 2013). Suppression of $c d c 13-1$ temperature sensitivity by pifl $\Delta$ has already been reported (Downey et al., 2006). We find that pifl $\Delta$ cannot suppress the temperature sensitivity of $c d c 13-1$ in a $t l c 1-t m$ background (Figure 1D). This result suggests that $t l c 1-t m$ telomeres remain uncapped even in the absence of Pif1 due to a lack of G-quadruplexes to stabilize.

We noticed that $c d c 13-1 \mathrm{tlcl-tm}$ cells grow more slowly than $c d c 13-1$ cells even at $25^{\circ} \mathrm{C}$ (Figure 1D), suggesting that G-quadruplex-mediated capping may be important even at a temperature where the Cdc13-1 mutant protein is only modestly impaired (Paschini et al., 2012). This effect is even more striking upon dissection of a $c d c 13-1 / C D C 13 \mathrm{tlc1-tm/TLC1}$ diploid: we find no difference in the colony size formed by the haploid progeny at $22^{\circ} \mathrm{C}$, regardless of their CDC13 and TLC1 status (Figure 1E). However, $c d c 13-1 \mathrm{tlcl}$-tm spores were unable to germinate at $25^{\circ} \mathrm{C}$ (Figure 1E), although the $c d c 13-1 \mathrm{tlcl}$-tm spores that germinated at $22^{\circ} \mathrm{C}$ were able to grow at $25^{\circ} \mathrm{C}$ (Figure 1D).

Despite the impaired ability of $t l c 1-t m$ telomeres to protect chromosome ends in $c d c 13-1$ strains, the viability of $t l c 1-t m$ cells is indistinguishable from wild-type cells in the presence of wild-type Cdc13 (Figure 1A), which is true even when cells harbor an artificial 
telomere consisting entirely of $t l c 1-t m$ telomeric sequence (see below), suggesting that the telomere protection function conferred by G-quadruplexes is not essential for cell viability and is only important when telomeres become uncapped.

\section{Rap1 binds poorly to $t l c 1-t m$ sequences}

Because telomerase only adds repeats to the distal end of telomeres, the proximal region of tlc1-tm telomeres still contains some wild-type repeats. Thus, we engineered strains in which the left arm of chromosome VII (VII-L) ends with a telomere that consists entirely of either wild-type or $t l c 1$-tm telomeric sequence (Figure 2A). These strains were constructed by replacing the native VII-L telomere with the $U R A 3$ gene followed by $81 \mathrm{bp}$ of wild-type or 84 bp of $t l c 1$-tm telomeric seed sequence, which was lengthened in vivo by either wild-type or $t l c 1$-tm mutant telomerase, respectively. As expected, the VII-L telomere containing only mutant sequence (VII-L-MUT) was longer and more heterogeneous than the wild-type control telomere (VII-L-WT) (Figure 2A). The two main sequence-specific telomere binding proteins in yeast are Cdc13 and Rap1, which bind single-stranded and double-stranded telomeric DNA, respectively (Lin and Zakian, 1996; Nugent et al., 1996; Buchman et al., 1988; Conrad et al., 1990). We assessed their association to the VII-L-WT or VII-L-MUT telomeres by chromatin immunoprecipitation coupled with quantitative PCR (ChIP-qPCR). We find that Cdc13 associates equally well with both the VII-L-WT and the VII-L-MUT telomeres (Figure 2B). Binding of Rap1, on the other hand, was substantially reduced at the VII-L-MUT telomere (Figure 2C). We confirmed the Rap1 ChIP result by performing an electrophoretic mobility shift assay (EMSA) using recombinant full-length Rap1 protein. We find that Rap1 shows a very poor binding capacity to the $t l c 1$-tm oligonucleotides compared to the wild-type telomeric sequence (Figure 2D). 
The ability of $t l c 1-t m$ strains to survive with greatly reduced Rap1 telomere association was surprising given that Rap1 is the main telomere binding protein in $S$. cerevisiae, important for recruiting a number of other proteins to telomeres, and is encoded by an essential gene. However, the essential function of Rap1 is likely linked to its ability to bind nontelomeric sites in the genome where it acts as a transcriptional regulator of several hundred genes (Azad and Tomar, 2016). In addition, S. cerevisiae strains expressing a mutant telomerase that adds vertebrate TTAGGG telomeric repeats are devoid of Rap1, indicating that Rap1 is not essential for telomere capping (Alexander and Zakian, 2003; Brevet et al., 2003). In these strains, Tbf1 binds to the vertebrate repeats and is able to regulate telomere length homeostasis in a Rap1-independent manner (Alexander and Zakian, 2003; Berthiau et al., 2006). Thus, we assessed binding of Tbf1 to $t l c 1-t m$ telomeres. We find no change in the levels of Tbf1 at $t l c 1$-tm telomeres compared to wild-type telomeres by ChIP-qPCR (Figure 2E), showing that the loss of Rap1 is not compensated by recruitment of Tbf1.

\section{Loss of Rap1-mediated telomere length regulation}

The decreased binding of Rap1 to $t l c 1$-tm sequences likely explains the long, heterogeneoussized telomeres in $t l c 1$-tm strains, because Rap1 negatively regulates telomerase through what is called the "protein counting" model. This model posits that Rap1, through its recruitment of Rif1 and Rif2, inhibits telomerase; the longer a telomere is, the more Rap1, Rif1, and Rif2 will be present, and the stronger the inhibition of telomerase will be (Marcand et al., 1997; Levy and Blackburn, 2004). Reduced binding of Rap1 would cause tlc1-tm telomeric sequences to not be recognized as telomeric in terms of Rap1-mediated telomere length regulation. To test this hypothesis, we again modified telomere VII-L to generate a telomere that would be seeded with either $84 \mathrm{bp}$ or $300 \mathrm{bp}$ of $t l c 1$-tm telomeric sequence, but in a $T L C 1$ strain expressing wild-type telomerase so that the tip of the telomere would contain 
wild-type telomeric sequences. In both cases, the size of the telomere VII-L terminal restriction fragment increased in size, with the magnitude of the increase roughly equivalent to the size of the $t l c 1$-tm telomeric seed sequence, indicating that this sequence is not being sensed as telomeric by the Rap1 protein counting mechanism (Figure 3A).

To examine telomere length regulation in $t l c l$-tm strains further, we monitored telomerase-mediated telomere extension events at nucleotide resolution after a single cell cycle using the iSTEX (inducible Single Telomere EXtension) assay (Strecker et al., 2017). At wild-type telomeres, telomerase extends only a subset of telomeres in each cell cycle, with a strong preference for the extension of short telomeres (Teixeira et al., 2004; Strecker et al., 2017). At $t l c 1-t m$ telomeres, we find that telomere extension frequency is dramatically increased, with nearly all (92\%) of telomeres being extended during a single cell cycle (Figure 3B and 3C). This observation is consistent with the protein counting model; the lack of Rap1 at $t l c 1$-tm telomeres causes them to all be recognized as short telomeres in need of elongation.

\section{tlc1-tm telomeres are rapidly degraded in the absence of telomerase}

The increase in telomere extension frequency of $t l c 1-t m$ telomeres is much more dramatic than the increase seen in rifl $\Delta$, rif2 $\Delta$, and pif1-m2 cells (Teixeira et al., 2004; Stinus et al., 2017), even though these mutants have similar or longer telomeres than the tlc1-tm mutant (e.g. see Figure 6 for comparison to rif1 $\Delta$ and rif2 $\Delta$ ). Ablation of Rap1 leads to readily detectable telomere degradation within a few hours (Vodenicharov et al., 2010), so we hypothesized that while decreased Rap1 at $t l c 1-t m$ telomeres may favor their extension by telomerase, increased degradation may limit the length of $t l c 1$-tm telomeres. If true, removal of telomerase should trigger rapid entry into senescence. To test this idea, we sporulated diploid strains that were heterozygous for EST2, which encodes the protein catalytic subunit 
of telomerase (Lingner et al., 1997), or TLC1, with either wild-type or mutant telomeres (i.e. est2A/EST2 versus est2A/EST2 tlc1-tm/tlc1-tm and tlc1 $1 / T L C 1$ versus $t l c 1 \Delta / t l c 1-t m$ ), and performed senescence assays with the haploid meiotic progeny. In the presence of wild-type telomeres but absence of telomerase (est2 $\Delta$ and $t l c 1 \Delta$ ), telomeres shortened until the cells senesced after 60 to 70 population doublings, as expected (Figure 4A). A small subset of the senescent population was then able to lengthen the telomeres by recombination-mediated mechanisms, forming so-called survivors (Lundblad and Blackburn, 1993). We found that cells containing mutant telomeres senesced rapidly, only 40 population doublings after telomerase loss (Figure 4A, est2 $\Delta \mathrm{tlcl-tm} *$ and $t l c 1 \Delta^{*}$ ). We examined the telomere length of cells that had undergone $\sim 30$ population doublings after isolation of the haploid spores and found that, upon loss of telomerase, mutant telomeres became extremely heterogeneous and degraded (i.e. a continuous smear of telomeric DNA-hybridizing signal extending from the wells to the bottom; Figure 4B).

\section{Rif1 and Sir4, but not Rif2 nor Sir3, association to tlc1-tm telomeres is decreased}

Rap1, through its C-terminal domain, recruits Rif1, Rif2, Sir3, and Sir4 to telomeres (Hardy et al., 1992; Wotton and Shore, 1997; Moretti et al., 1994). We reasoned that the reduction of Rap1 at the tlc1-tm telomeres should also decrease recruitment of Rif1, Rif2, Sir3, and Sir4, which we tested by ChIP-qPCR (Figure 5A). Consistent with this hypothesis, we find that Rif1 and Sir4 recruitment to the VII-L-MUT telomere is reduced compared to the VII-L-WT telomere (to $16 \%$ for Rif1 and $31 \%$ for Sir4). Surprisingly, the recruitment of neither Rif 2 nor Sir3 is affected. Rif2 can interact with the Xrs2 and Rad50 subunits of the MRX complex (Hirano et al., 2009; Hailemariam et al., 2019), which binds to DNA ends and telomeres (Oh and Symington, 2018); Rif2 can also interact directly with double-strand DNA (Cassani et al., 2016; Hailemariam et al., 2019). Sir3 possesses multiple domains that can interact with 
histones (Gartenberg and Smith, 2016). Thus, Rif2 and Sir3 may associate to tlc1-tm telomeres via Rap1-independent mechanisms.

\section{Transcription is not affected at $\mathrm{tlcl}$-tm telomeres}

Rap1, through its recruitment of the Rif and Sir proteins, represses the transcription of noncoding telomeric repeat-containing RNA (TERRA; Iglesias et al., 2011). Reduced levels of Rap1, Rif1, and Sir4 at tlc1-tm telomeres may alter TERRA transcription. However, we find no change in TERRA abundance in $t l c 1$-tm cells (Figure 5B). Rap1, through its recruitment of the Sir complex, also mediates the transcriptional silencing of subtelomeric genes (Moretti et al., 1994). The VII-L-WT and VII-L-MUT telomeres possess a $U R A 3$ gene immediately adjacent to the telomeric repeats. Silencing of the URA3 gene was monitored by assaying for growth in the presence of 5-fluoroorotic acid (5-FOA), which kills cells expressing URA3 (Figure 5C). Strains deleted for SIR2, which causes a defect in silencing (Aparicio et al., 1991), were used as controls. Because hypersensitivity to 5-FOA does not correlate with loss of silencing in some genetic backgrounds (Rossmann et al., 2011), we also measured URA3 transcript levels by reverse-transcriptase quantitative PCR (Figure 5D). In both assays, we find no difference between VII-L-WT and VII-L-MUT, indicating that the reduced levels of Rap1 and Sir4 at tlc1-tm telomeres still allow functional silencing.

\section{Rif2 prevents degradation of $t l c 1-t m$ telomeres}

Rap1 regulates telomere length homeostasis through its recruitment of Rif1, Rif2, and Sir4. Rif1 and Rif2 negatively regulate telomerase (Hardy et al., 1992; Wotton and Shore, 1997; Levy and Blackburn, 2004). In contrast, Sir4 functions in a pathway to recruit telomerase to telomeres (Hass and Zappulla, 2015). We tested what effect deleting RIF1, RIF2, and SIR4 would have on telomere length in $t l c 1$-tm cells. Deletion of SIR4 results in a small decrease in 
telomere length in TLCl cells, as expected (Hass and Zappulla, 2015), but no noticeable change in tlc1-tm cells (Figure 6A). The lack of an effect could be due to Sir4 already being reduced at tlc1-tm telomeres (Figure 5A). Deletion of RIF1 increases telomere length in both TLC1 and tlc1-tm cells (Figure 6B), despite an even bigger reduction of Rif1 at tlcl-tm telomeres (Figure 5A). Rif1 may still impact $t l c 1-t m$ telomeres because it plays a much bigger role in telomere length homeostasis than Sir4.

Deletion of RIF2 causes dramatic degradation of $t l c 1-t m$ telomeres, with a continuous smear of telomeric DNA-hybridizing signal observed, similar to tlcl-tm cells upon loss of telomerase (Figure 4B). This finding, along with the observation that Rif2 is still present at tlcl-tm telomeres (Figure 5A), indicates that Rif2 has an important role in protecting $t l c 1-t m$ telomeres. Since uncapped telomeres expose chromosome ends to non-homologous end joining (NHEJ) and homologous recombination (HR), we tested whether the rif2 $\Delta$ tlcl-tm telomere profile would change by deleting $D N L 4$ or $R A D 52$, which are required for NHEJ and HR, respectively (Wilson et al., 1997; Symington et al., 2014). The extensive smear was

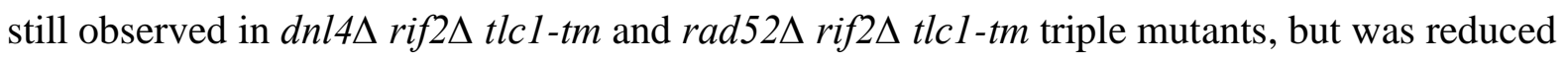

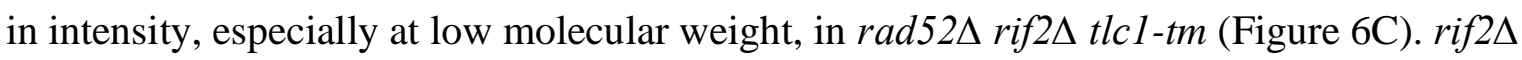
tlcl-tm cells grow poorly, and this growth defect is exacerbated by additional deletion of RAD52; rad52 $\operatorname{rif} 2 \Delta$ tlcl-tm spores mostly fail to germinate, and those that do grow even more poorly than rif2 $\mathrm{tlcl}$-tm (Figure 6D-E), suggesting that Rad52-mediated HR helps cope with rif2 2 tlc1-tm uncapped telomeres.

Interestingly, rifl $\Delta$ rif $2 \Delta$ and rifl $\Delta$ rif $2 \Delta$ tlcl-tm cells have very similar telomere profiles: very long telomeres but without the extensive degradation seen in rif $2 \Delta$ tlcl-tm cells (Figure 6B). This observation is reminiscent of the elevated levels of telomere-telomere fusion seen in rif $2 \Delta$ tell $\Delta$ cells, and not in rifl $\Delta$ rif2 $\Delta$ tell $\Delta$ cells (Marcand et al., 2008), but 
it is currently unclear whether there is a common underlying mechanism that explains both observations.

\section{Rif2 protects $t l c 1-t m$ telomeres by inhibiting the MRX complex}

TEL1 is epistatic to RIF2 with respect to telomere length regulation; while rif $2 \Delta$ cells have long telomeres, tell $\Delta$ and rif2 $\Delta$ tell $1 \Delta$ cells have very short telomeres (Craven and Petes, 1999). Thus, we tested whether the same would be true in terms of the telomere degradation seen in rif2 $\Delta$ tlcl-tm cells. Deletion of TEL1 shortens the telomeres of $t l c 1$-tm cells, but does not affect the telomere profile of rif $2 \Delta \mathrm{tlcl}$-tm cells (Figure 6B), indicating that Rif2 does not inhibit Tel1 to prevent the degradation of $t l c 1$-tm telomeres. Recent studies have shown that Rif2 attenuates Tel1 activity at telomeres by inhibiting the MRX complex (consisting of Mre11, Rad50, and Xrs2), which is responsible for recruiting Tel1 to telomeres (Hailemariam et al., 2019; Sabourin et al., 2007). Rif2 discharges the ATP-bound state of Rad50, thereby making the MRX complex incapable of activating Tel1 (Hailemariam et al., 2019). Similarly, Rif2 enhancement of Rad50 ATPase activity limits MRX-mediated tethering of DNA ends during double-strand break repair (Cassani et al., 2016). Therefore, we hypothesized that Rif2 could be inhibiting MRX-mediated degradation of $t l c 1-t m$ telomeres. Consistent with this idea, we find that Mre11 is about fivefold more associated with the VII-L-MUT telomere in comparison with the VII-L-WT telomere (Figure 7A), and that the telomere degradation

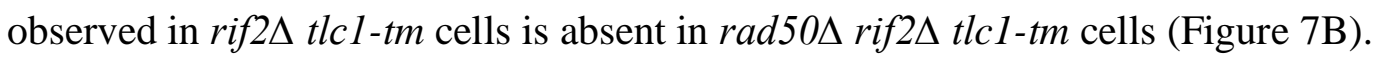

\section{Rif2 and the Yku complex act in parallel to protect tlc1-tm telomeres}

The CST (Cdc13-Stn1-Ten1) and Yku (Yku70-Yku80) complexes are also important for inhibiting nucleolytic degradation at telomeres (Garvik et al., 1995; Grandin et al., 1997; Grandin et al., 2001; Gravel et al., 1998), and their importance might be increased at tlc1-tm 
telomeres. Cdc13 and Yku70 are present at similar levels at VII-L-WT and VII-L-MUT telomeres (Figure 2B; Figure 7C). $c d c 13-1 \mathrm{tlcl}$-tm cells grow more poorly than $c d c 13-1$ cells (Figure 1D-E), but do not exhibit the extensive telomere degradation seen in rif2 $\mathrm{tlcl}$-tm cells (Figure 7B). In contrast, we observe extensive telomere degradation in yku70 $\mathrm{tlcl}$-tm

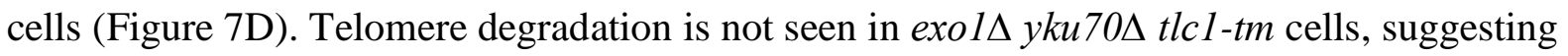
that the Yku complex inhibits the Exo1 exonuclease to protect $t l c 1$-tm telomeres. rif $2 \Delta$ $y k u 70 \Delta$ tlcl-tm cells are not viable (Figure 7E), indicating that Rif2 and the Yku complex function in parallel to protect $t l c 1-t m$ telomeres.

\section{Discussion}

In this study, we investigated the function of G-quadruplexes and Rap1 at S. cerevisiae telomeres in the tlcl-tm mutant, which causes the addition of mutant telomeric repeats that are defective in forming G-quadruplexes and association with Rap1. Our findings suggest that impairing G-quadruplex formation and Rap1 binding does not significantly affect cell proliferation. The depletion of telomeric Rap1 causes defects in telomere length regulation and telomere capping. $t l c 1$-tm telomeres become extensively degraded in the absence of Rif2 or the Yku complex, and rif2 $24 k u 70 \Delta$ tlc1-tm triple mutants are inviable. Thus, Rap1, Rif2, and the Yku complex perform separate tasks that are together essential for telomere capping and cell viability.

\section{Rap1 works in concert with Rif 2 and the Yku complex to prevent telomere degradation}

Telomere capping is essential for cell viability; yeast cells cannot survive the loss of a single telomere (Sandell and Zakian, 1993). Telomere capping is executed by telomere-binding proteins, so it was surprising to find that yeast cells can survive when Rap1, the main protein that binds double-stranded telomeric DNA, is significantly reduced at telomeres. Previous 
studies have reported that telomeres of $S$. cerevisiae expressing mutant telomerase that adds TTAGGG repeats are also devoid of Rap1; however, the absence of Rap1 in this situation appears to be compensated by the binding of Tbf1 to the TTAGGG sequence (Alexander and Zakian, 2003; Brevet et al., 2003; Berthiau et al., 2006). In contrast, there is no change in Tbf1 binding at $t l c 1$-tm telomeres (Figure 2E). In addition, multiple viable $t l c 1$ template mutants, including $t l c 1-t m$, result in the addition of mutant telomeric sequence that simultaneously alters the consensus binding sites of both Rap1 and Tbf1 (Prescott and Blackburn, 2000; Förstemann et al., 2003; Lin et al., 2004), supporting the notion that telomeres can remain sufficiently capped in the absence of both proteins.

Previously studied $t l c 1$ template mutations that abolish Rap1 binding to the resulting mutant telomere sequences generally fall into two categories; they either cause telomere shortening or they cause rapid telomere elongation, which in some cases is accompanied by extensive telomere degradation (Prescott and Blackburn, 2000; Lin et al., 2004), similar to that seen in rif2 $\Delta$ tlcl-tm mutants (Figure 6B). The first category is likely due to a loss of telomerase enzymatic activity, because most $t l c 1$ template mutations result in a reduction in the nucleotide addition processivity of telomerase (Förstemann et al., 2003). The extent of telomere elongation and degradation in the second category appears to be correlated with the decrease in Rap1 binding (Prescott and Blackburn, 2000). Rap1 association to tlcl-tm telomeres is reduced to approximately 13\% compared to wild-type telomeres (Figure 2C). We suspect that this level of Rap1 prevents the more extensive elongation and degradation seen in several other $t l c 1$ template mutants (e.g. $t l c 1-476 g C A$ ) that likely have even less Rap1 telomere association (Prescott and Blackburn, 2000; Lin et al., 2004). Consistent with this hypothesis, $t l c 1 \Delta$ cells derived from the sporulation of $t l c 1-t m / t l c 1 \Delta$ diploids with mutant telomeres also exhibit extensive degradation (Figure 4B), which is likely the result of further reducing Rap1 telomere association due to telomere shortening. 
Our findings indicate that Rap1 and Rif2 inhibit the MRX complex to prevent telomere degradation. First, decreased telomere association of Rap1 in tlc1-tm cells (Figure 2C) is accompanied by an increase in Mre11 telomere association (Figure 7A), which is consistent with a previous report showing that Rap1 binding inhibits Mre11 recruitment (Negrini et al., 2007). Second, the telomere degradation observed in rif2 $2 \mathrm{tlcl-tm}$ cells is eliminated by deletion of RAD50 (Figure 7B), which is consistent with previous studies showing that Rif2 inhibits the MRX complex by discharging the ATP-bound form of Rad50 (Cassani et al., 2016; Hailemariam et al., 2019). Rap1 and Rif2 inhibition of the MRX complex functions in parallel with the Yku complex, which inhibits Exo1-mediated telomere degradation in $t l c 1$-tm cells (Figure 7D), as rif2 $4 k u 70 \Delta$ tlcl-tm cells are inviable (Figure 7E). Thus, Rap1/Rif2 and the Yku complex define separate pathways to inhibit telomere degradation (Figure 7F).

The redundant capping mechanisms offer an explanation for the rapid evolution of the telomere sequence and telomere binding proteins in budding yeast species of the Saccharomycotina subdivision, of which S. cerevisiae is a member (Steinberg-Neifach and Lue, 2015). Alterations in the template region of telomerase RNA or in the DNA binding domain of telomere-binding proteins are more easily tolerated if there are redundant mechanisms to ensure sufficient telomere capping and, therefore, cell viability. Indeed, the budding yeast Kluyveromyces lactis can also tolerate changes to the template region of its telomerase RNA that disrupts binding to Rap1 (Krauskopf and Blackburn, 1996). The more distantly related fission yeast Schizosaccharomyces pombe can also survive without its main telomere-binding protein, Taz1 (Cooper et al., 1997), suggesting that redundancy of telomere capping mechanisms has also evolved independently outside of the Saccharomycotina subdivision. 


\section{The role of G-quadruplexes at $S$. cerevisiae telomeres}

Formally, it is possible that the depletion of telomere-bound Rap1 and resulting telomere defects observed in $t l c 1$-tm cells are due to impaired telomeric G-quadruplex formation. We believe this scenario is unlikely because the Rap1 EMSA experiment (Figure 2D) was performed in conditions that lack cations (e.g. $\mathrm{K}^{+}$and $\mathrm{Na}^{+}$) that favor G-quadruplex formation (Bhattacharyya et al., 2016). Thus, the decrease in Rap1 telomere association at tlc1-tm telomeres, as assessed by ChIP-qPCR (Figure 2C), is most likely due to decreased binding of Rap1 to double-stranded telomeric DNA rather than telomeric G-quadruplexes, especially considering that the majority of telomeric DNA is expected to be double stranded in vivo. While our findings do not support a major role for G-quadruplexes at S. cerevisiae telomeres in normal (i.e. not $c d c 13-1$ ) conditions, we are still left with the question of why telomeres in most eukaryotic organisms have sequences with the potential of forming Gquadruplexes. The telomere repeats of S. cerevisiae and other Saccharomycotina species are highly divergent and differ from the TTAGGG or TTAGGG-like repeats found in many other eukaryotic species. Budding yeast repeats can be quite long, occasionally degenerate, and often non-G/C-rich (Cohn et al., 1998; Steinberg-Neifach and Lue, 2015). Many of the budding yeast telomere sequences do not conform to the $\mathrm{G}_{\geq 3} \mathrm{~N}_{\mathrm{x}} \mathrm{G}_{\geq 3} \mathrm{~N}_{\mathrm{x}} \mathrm{G}_{\geq 3} \mathrm{~N}_{\mathrm{x}} \mathrm{G}_{\geq 3}$ G-quadruplex consensus. Changes in the sequence of the telomeric repeats were accompanied by coevolution of telomere-binding proteins. In organisms with TTAGGG telomeric repeats, the double-stranded telomeric sequence is typically recognized by proteins homologous to mammalian TRF1 and TRF2, while the single-stranded telomeric sequence is bound by proteins homologous to mammalian POT1. Telomere association of these proteins is highly sequence specific (Broccoli et al., 1997; Loayza et al., 2004), so mutating the template region of telomerase RNA leads to a loss of cell viability (Marušić et al., 1997; Guiducci et al., 2001; Kim et al., 2001). In contrast, the telomeres of Saccharomycotina budding yeast 
species (with the exception of the Yarrowia clade, one of the basal lineages of Saccharomycotina (Červenák et al., 2019)) are bound by Rap1 and Cdc13. Rap1 and Cdc13 have the possibility to accommodate different target sequences, thereby facilitating the rapid evolution of budding yeast telomeric sequences (Steinberg-Neifach and Lue, 2015). A consequence of this rapid evolution may be the loss of a need for telomeric G-quadruplexes. Further studies are needed to determine whether G-quadruplexes are required for proper telomere maintenance in species with TTAGGG telomeric repeats. One recent study has reported that folding of telomeric DNA newly synthesized by human telomerase into Gquadruplexes is important to support telomerase function, which the authors suggest could provide an explanation for the evolutionary conservation of the G-quadruplex-forming potential of telomeric sequence (Jansson et al., 2019). Addressing this question is especially relevant given that G-quadruplexes have increasingly been proposed as therapeutic targets in oncology (Balasubramanian et al., 2011).

If both G-quadruplexes and Rap1 are not essential for telomere capping in $S$. cerevisiae, why does Rap1 have the ability to bind and promote the formation of Gquadruplexes (Giraldo and Rhodes, 1994; Traczyk et al., 2020)? We propose two possible explanations. First, this ability may have been required for telomere capping, but this requirement was lost during the evolution of the Saccharomycotina subdivision. Rudimentary G-quadruplex-based capping in $c d c 13-1$ mutants (Smith et al., 2011) may be an evolutionary remnant of this requirement, so it would be interesting to test whether suppression of $c d c 13-1$ capping defects by G-quadruplex-stabilizing treatments is dependent on Rap1. Second, the ability of Rap1 to bind and promote the formation of G-quadruplexes may be important for Rap1's function as a transcriptional regulator (Azad and Tomar, 2016), rather than for telomere capping. Consistent with this hypothesis, G-quadruplex-forming sequences are strongly enriched at promoters and are thought to influence transcription (Varshney et al., 
2020). These two hypotheses are not mutually exclusive, and it will be interesting to explore their validity in future studies.

\section{Acknowledgments}

We thank K. Paeschke for critical reading of the manuscript; S. Pandey and O. Rosas Bringas for help with data analysis; and H.G. Kazemier for technical assistance. F.R.R.B. was supported by a CONACYT scholarship. S.S. was supported by an EMBO Short-Term Fellowship to visit the lab of B. Luke to perform TERRA measurements and to gain experience with ChIP-qPCR experiments, and we thank B. Luke and M. Graf for their technical assistance. M. Cohn was supported by grants from the Carl Trygger Foundation, the Erik Philip-Sörensen Foundation, and the Royal Physiographic Society in Lund. Work in the laboratory of M. Chang was supported by a Vidi grant from the Netherlands Organization for Scientific Research.

\section{Author Contributions}

Conceptualization, F.R.R.B., S.S., M. Chang; Investigation, F.R.R.B., S.S., L.W., P.Z., M.

Cohn; Writing - Original Draft, F.R.R.B., S.S., M. Chang; Writing - Reviewing \& Editing, F.R.R.B., S.S., L.W., P.Z., M. Cohn, M. Chang; Supervision, M. Chang.

\section{Declaration of Interests}

The authors declare no competing interests. 


\section{Figure Titles and Legends}

\section{Figure 1. tlc1-tm mutant telomere sequences are impaired in forming G-quadruplexes}

(A) Exponentially growing cells of the indicated genotypes were diluted to an $\mathrm{OD}_{600}$ of 0.05 and monitored for $8 \mathrm{~h}$. Three clones of each genotype were followed, and the average of the measurements at each time point is plotted.

(B) Telomere Southern blot analysis of TLC1 and tlc1-tm cells (three clonal isolates per genotype). Black arrowhead indicates a $1.8 \mathrm{~kb}$ DNA fragment generated from the BsmAIdigestion of plasmid pYt103 (Shampay et al., 1984). The major terminal restriction fragment is below the $1.8 \mathrm{~kb}$ control band.

(C) CD spectra of oligonucleotides with either wild-type or $t l c 1-t m$ telomeric sequence. Average of three measurements is plotted.

(D) Tenfold serial dilutions of strains with the indicated genotypes were spotted on YPD plates and grown at $25^{\circ} \mathrm{C}$ or $30^{\circ} \mathrm{C}$.

(E) A $c d c 13-1 / C D C 13 t l c 1-t m / T L C 1$ diploid strain was sporulated and the resulting tetrads were dissected on YPD plates, which were incubated at $22^{\circ} \mathrm{C}$ or $25^{\circ} \mathrm{C}$. Each column of colonies arose from a single tetrad.

\section{Figure 2. Rap1 binds poorly to tlc1-tm telomeres}

(A) Southern blot analysis of the artificial VII-L telomere, with either wild-type or $t l c 1-t m$ mutant sequence, using a probe to the adjacent $U R A 3$ gene. Multiple clones were examined, with each clone propagated for 1 to 4 passages. A wild-type strain (lacking the artificial VIIL telomere) was used as a control.

(B, C, E) ChIP-qPCR analysis of the association of (B) Myc-tagged Cdc13, (C) Protein Atagged Rap1, and (E) Myc-tagged Tbf1 to the VII-L telomere or to the non-telomeric ARO1 
locus. Untagged wild-type and $t l c 1$-tm strains were used as controls. The mean percentage of input \pm SEM is shown $(\mathrm{n}=3, * * \mathrm{p}<0.01)$.

(D) EMSA of Rap1 protein incubated with radiolabeled oligonucleotides with either wildtype or $t l c 1$-tm mutant telomeric sequence.

\section{Figure 3. Telomere length regulation is disrupted in tlc1-tm cells}

(A) Southern blot analysis of the artificial VII-L telomere using a probe to the adjacent URA3 gene. The telomere was seeded with either wild-type or $t l c 1$-tm mutant sequence of the indicated lengths in a strain expressing wild-type TLC1. Multiple clones of each strain were examined. A wild-type strain (lacking the artificial VII-L telomere) was used as a control. (B) In vivo extension of $t l c 1$-tm telomeres was examined using the iSTEX assay. Telomere VI-R was amplified and sequenced after the induction of wild-type telomerase. Each bar represents an individual telomere. The black and red portions of each bar represent wild-type and $t l c 1$-tm sequence, respectively, that is identical in sequence and thus present before telomerase induction. Sequence that is divergent from the black and red sequence is shown in grey and green. Grey represents newly added wild-type sequence after the induction of telomerase. Green represents divergent $t l c 1$-tm sequence, most likely a result of homologous recombination. Telomeres are sorted based on the length of the undiverged (black plus red) sequence.

(C) Telomere VI-R sequences obtained from the iSTEX analysis in B were binned into groups of $10 \mathrm{nt}$ in size according to telomere length before telomerase induction. iSTEX data for the extension of wild-type telomeres were taken from previous studies (Strecker et al., 2017; Stinus et al., 2017) and included for comparison. Groups containing less than four telomeres were excluded from this analysis. Frequency of extension and average telomere length before telomerase induction were calculated and plotted for each group. Logarithmic 
bioRxiv preprint doi: https://doi.org/10.1101/2020.12.30.424824; this version posted December 30, 2020. The copyright holder for this preprint (which was not certified by peer review) is the author/funder, who has granted bioRxiv a license to display the preprint in perpetuity. It is made available under aCC-BY-NC-ND 4.0 International license.

regression curves for each data set were also included in the plot. Telomeres shorter than 40 nt before telomerase induction, which are not efficiently recognized and extended by telomerase (Strecker et al., 2017), were removed from the regression analysis.

\section{Figure 4. Fast degradation of $t l c 1-t m$ telomeres in the absence of telomerase}

(A) Senescence rates were measured by serial passaging of strains of the indicated genotypes, derived from the sporulation of est2 $4 / E S T 2$ and est2 $4 / E S T 2$ tlc1-tm/tlc1-tm diploids (top panel) or $t l c 1 \Delta / T L C 1$ and $t l c 1 \Delta / t l c 1$-tm diploids (bottom panel). Cell density was measured every $24 \mathrm{~h}$, followed by dilution to $1 \times 10^{5}$ cell $/ \mathrm{ml}$. Mean $\pm \mathrm{SEM}$ of four independent isolates per genotype is plotted.

(B) Telomere Southern blot analysis of samples obtained at the first time point of the senescence assays in A. Black arrowhead indicates the $1.8 \mathrm{~kb}$ telomere sequence-containing fragment loaded as control, as in Figure 1B.

Figure 5. Recruitment of Rif1 and Sir4, but not Rif2 nor Sir3, is significantly reduced at tlc1-tm telomeres

(A) ChIP-qPCR analysis of the association of Myc-tagged Rif1, Rif2, Sir4, and Protein Atagged Sir3 to the VII-L telomere or to the non-telomeric AROI locus. Untagged wild-type and $t l c 1-t m$ strains were used as controls.

(B) Total RNA was reverse transcribed and TERRA from specific telomeres (I-L and XV-L) was analyzed by qPCR. TERRA values were normalized to ACT1 levels, and to the respective wild type (TLC1).

(C) Tenfold serial dilutions of strains with the indicated genotypes were spotted on SC plates without or with 5-FOA. 
(D) The expression of the subtelomerically integrated URA3 gene was measured in the indicated yeast strains by RT-qPCR.

All data (except $\mathrm{C})$ are shown as mean $\pm \operatorname{SEM}\left(\mathrm{n}=3, * * * \mathrm{p}<10^{-3}, * * * * \mathrm{p}<10^{-4}\right)$.

\section{Figure 6. Rif2 prevents degradation of tlc1-tm telomeres}

(A-C) Telomere Southern blot analysis of strains of the indicated genotypes. Black arrowhead indicates the $1.8 \mathrm{~kb}$ telomere sequence-containing fragment loaded as control, as in Figure 1B.

(D) Colony sizes of haploid meiotic progeny derived from the sporulation of $\operatorname{rad} 52 \Delta / R A D 52$ rif2 $2 / R I F 2$ and $\mathrm{rad} 52 \Delta / R A D 52$ rif2 $\Delta /$ RIF2 $\mathrm{tlcl}$-tm/tlcl-tm diploid strains were measured and normalized to wild-type (top panel) or $t l c 1$-tm (bottom panel). The number of colonies analyzed is indicated in parenthesis. Error bars show SEM.

(E) Tenfold serial dilutions of strains with the indicated genotypes were spotted on YPD plates and grown at $30^{\circ} \mathrm{C}$.

Figure 7. Rif2 protects $t l c 1-t m$ telomeres by inhibiting the MRX complex and acts in parallel with the Yku complex

(A\&C) ChIP-qPCR analysis of the association of Myc-tagged Mre11 and Yku70 to the VII-L telomere or to the non-telomeric ARO1 locus. Untagged wild-type and tlcl-tm strains were used as controls. The mean percentage of input \pm SEM is shown $(n=3, * * p<0.01)$. (B\&D) Telomere Southern blot analysis of strains of the indicated genotypes. Black arrowhead indicates the $1.8 \mathrm{~kb}$ telomere sequence-containing fragment loaded as control, as in Figure 1B. (B) Parental diploid 1 is $\mathrm{rad50 \Delta /RAD50}$ rif2 $\Delta / R I F 2$; parental diploid 2 is $\mathrm{rad50 \Delta /RAD50}$ rif2 $/ \mathrm{RIF} 2 \mathrm{tlcl}$-tm/tlcl-tm. The last six lanes are derived from cells grown at 
$22^{\circ} \mathrm{C}$. (D) Parental diploid 1 is exo $1 \triangle / E X O 1$ yku70 $/ Y K U 70$; parental diploid 2 is

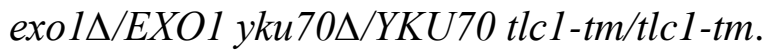

(E) Colony sizes of haploid meiotic progeny derived from the sporulation of rif $2 \Delta / R I F 2$

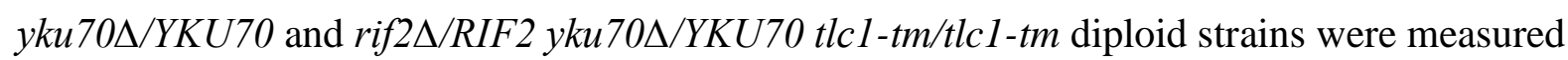
and normalized to wild-type (top panel) or tlcl-tm (bottom panel). The number of colonies analyzed is indicated in parenthesis. Error bars show SEM. Representative images of dissected tetrads are shown on the right. Each column of colonies arose from a single tetrad. (F) A model to illustrate how Rap1, Rif2, and the Yku complex work in concert to prevent telomere degradation.

\section{Experimental Procedures}

\section{Yeast strains and plasmids}

Standard yeast media and growth conditions were used (Sherman, 2002; Lundblad and Struhl, 2010). Yeast strains used in this study are listed in Table S1. The artificial VII-L telomere was created essentially as previously described (Gottschling et al., 1990), by transforming restriction-digested pVII-L URA-TEL plasmid into yeast. To obtain different versions of the VII-L telomere, this plasmid was modified by replacing the original $81 \mathrm{bp}$ of telomeric repeats with oligonucleotides containing wild-type or $t l c 1$-tm telomeric sequence of different length (Table S2). Myc and protA C-terminal epitope-tagged proteins were created by integrative transformation of 13 copies of the human c-myc (Myc) epitope or the Staphylococcal protein A IgG binding domain.

\section{CD spectroscopy}

Oligonucleotides were dissolved in a $10 \mathrm{mM}$ Tris- $\mathrm{HCl} \mathrm{pH} 7.5$ and $100 \mathrm{mM} \mathrm{KCl}$ solution in a final concentration of $5 \mu \mathrm{M}$. The mix was boiled for 5 min at $95^{\circ} \mathrm{C}$ and then cooled down 
overnight. The CD spectra were then measured using a Jasco J-815 spectropolarimeter. Three reads per sample were taken at a wavelength range of $215-350 \mathrm{~nm}$ in a quartz cuvette with a $1 \mathrm{~cm}$ path length. Data were analyzed using Spekwin32 software.

\section{Southern blotting}

Southern blots to detect native telomeres were performed essentially as previously described (van Mourik et al., 2018). Yeast genomic DNA was isolated using a Wizard Genomic DNA Purification Kit (Promega) and digested with XhoI. For each sample, $4 \mu \mathrm{g}$ of digested genomic DNA, along with 1.25 ng of BsmAI-digested pYT103 (Askree et al., 2004), was separated on a $0.8 \%(\mathrm{w} / \mathrm{v})$ agarose gel, and transferred to a Hybond-N+ membrane (GE Healthcare). The membrane was hybridized to telomere-specific digoxygenin-labeled probe (wild type probe: 5'-CACCACACCCACACACCACACCCACA-3'; tlc1-tm mutant probe: 5'-ACCACACCACACCACACACACCACAC-3'). For detection of the artificial VII-L telomere, a similar procedure was performed, except that $6 \mu \mathrm{g}$ yeast genomic DNA was digested with EcoRV and the membrane was hybridized at $42^{\circ} \mathrm{C}$ with a digoxigenin-labeled probe complementary to $U R A 3$ sequence.

\section{Chromatin immunoprecipitation and quantitative PCR (ChIP-qPCR)}

ChIP-qPCR was performed essentially as previously described (Graf et al., 2017). For protein A ChIP, IgG Sepharose 6 Fast Flow beads (GE Healthcare) were used. For Myc ChIP, nProtein A Sepharose 4 Fast Flow beads (GE Healthcare) were used; after preclearing, $9 \mu 1$ anti-c-Myc Monoclonal antibody (Clontech/Takara) were added to each sample. qPCR was performed using a LightCycler 480 II (Roche) and SYBR-Green (Thermo Scientific) detection with an annealing temperature of $60^{\circ} \mathrm{C}$ (40 cycles). Primers are listed in Table S3. Measured Cq values were corrected to input and graphs were created using R. 


\section{Electrophoretic mobility shift assay (EMSA)}

The recombinant S. cerevisiae Rap1 full-length protein was expressed in E. coli BL21 cells as previously described (Wahlin and Cohn, 2000). The ability of Rap1 to bind the tlcl-tm telomeric sequences was assessed by EMSA with two double-stranded (ds) oligonucleotides containing representative sequences; Mut-1 5'-

GTCATACGTCACACTGTGGTGTGTGGTGTGGTGTGTGGTGGTGGTGTGTGT-3' (37

bp) and Mut-2 5'-

GTCATACGTCACACTGTGGTGTGTGTGGTGTGTGGATTTGGTGTGTGG-3' (34 bp).

The respective G-rich forward strands and C-rich reverse strands were annealed in $1 \mathrm{mM}$ Tris- $\mathrm{HCl}, \mathrm{pH} 8.0,0.1 \mathrm{mM} \mathrm{MgCl} 2$ by boiling for $2 \mathrm{~min}$ and slowly cooling down to room temperature. The correct annealing was guided by the $14 \mathrm{nt}$ non-telomeric region indicated in italics. A ds-oligonucleotide with wild-type telomeric sequence was used as the positive binding control: 5'-TGTGGTGTGTGGGTGTGTG-3' (19 bp). The 5' ends of ds-probes were radioactively labelled with $\left[\gamma_{-}{ }^{32} \mathrm{P}\right]-\mathrm{ATP}$ using T4 polynucleotide kinase (New England Biolabs), purified on Illustra Microspin G-25 columns (GE), and diluted in $10 \mathrm{mM}$ Tris- $\mathrm{HCl}$, $\mathrm{pH}$ 7.5. In binding assays, $10 \mathrm{fmol}$ of labelled probe was mixed with $1.5 \mu \mathrm{g}$ competitor mix (0.5 $\mu \mathrm{g}$ each of sheared E.coli DNA ( 250 bp), salmon sperm DNA, and yeast t-RNA) in 1x Binding buffer (10 mM Tris- $\mathrm{HCl}, \mathrm{pH} 7.5,7 \mathrm{mM} \mathrm{MgCl} 2,8 \%$ glycerol), and varying amounts $(\sim 0.1-0.4 \mu \mathrm{g})$ of Rap1 protein extract, in a total of $15 \mu$ l. The binding reaction was incubated at $25^{\circ} \mathrm{C}$ for $15 \mathrm{~min}$ and then loaded onto $4 \%$ polyacrylamide gels (29:1 acrylamide:bisacrylamide) and run in 1x TBE (89 mM Tris-borate, $2 \mathrm{mM}$ EDTA, $\mathrm{pH} 8.0), 150 \mathrm{~V}$ at $4^{\circ} \mathrm{C}$. Radioactive signals from dried gels were visualized with a Typhoon FLA 9500 biomolecular imager (GE Life Sciences). 


\section{Inducible STEX (iSTEX) assay}

iSTEX was performed essentially as previously described (Strecker et al., 2017), except that the starting $\mathrm{P}_{G A L L-E S T 1}$ strain contained the $t l c 1-t m$ allele. This strain was then transformed with a PCR product containing the wild-type $T L C 1$ allele and immediately grown on media containing glucose, which shut off expression of EST1. Successfully transformed cells were cultured in YPD media and eventually arrested in late G1 phase by the addition of alpha factor (Sigma-Aldrich). Cells were washed and resuspended in YPGal to induce the expression of wild-type telomerase, allowing the extension of tlcl-tm mutant telomeres during a single cell division.

\section{Liquid culture senescence assay}

Senescence assays in liquid culture were performed essentially as previously described (van Mourik et al., 2016).

\section{TERRA and URA3 level analysis by quantitative reverse transcription and PCR}

TERRA levels were measured essentially as previously described (Graf et al., 2017), while URA3 and ACT1 levels were measured by one-step RT-PCR with specific primers (Table S3) following the standard protocol of the RNeasy® Mini kit (Qiagen). 


\section{Supplemental Information Titles and Legends}

Table S1. Yeast strains used in this study.

Table S2. Wild-type and mutant sequences used to replace the VII-L telomere.

Table S3. qPCR primers. 


\section{References}

Alexander, M.K., and Zakian, V.A. (2003). Rap1p telomere association is not required for mitotic stability of a $\mathrm{C}_{3} \mathrm{TA}_{2}$ telomere in yeast. EMBO J 22, 1688-1696.

Aparicio, O.M., Billington, B.L., and Gottschling, D.E. (1991). Modifiers of position effect are shared between telomeric and silent mating-type loci in S. cerevisiae. Cell 66, 1279-1287.

Askree, S.H., Yehuda, T., Smolikov, S., Gurevich, R., Hawk, J., Coker, C., Krauskopf, A., Kupiec, M., and McEachern, M.J. (2004). A genome-wide screen for Saccharomyces cerevisiae deletion mutants that affect telomere length. Proc Natl Acad Sci U S A 101, 86588663.

Azad, G.K., and Tomar, R.S. (2016). The multifunctional transcription factor Rap1: a regulator of yeast physiology. Front Biosci (Landmark Ed) 21, 918-930.

Balasubramanian, S., Hurley, L.H., and Neidle, S. (2011). Targeting G-quadruplexes in gene promoters: a novel anticancer strategy? Nat Rev Drug Discov 10, 261-275.

Berthiau, A.S., Yankulov, K., Bah, A., Revardel, E., Luciano, P., Wellinger, R.J., Geli, V., and Gilson, E. (2006). Subtelomeric proteins negatively regulate telomere elongation in budding yeast. EMBO J 25, 846-856.

Bhattacharyya, D., Mirihana Arachchilage, G., and Basu, S. (2016). Metal Cations in GQuadruplex Folding and Stability. Front Chem 4, 38.

Brázda, V., Kolomaznik, J., Lýsek, J., Bartas, M., Fojta, M., Št’astný, J., and Mergny, J.-L. (2019). G4Hunter web application: a web server for G-quadruplex prediction. Bioinformatics $35,3493-3495$.

Brevet, V., Berthiau, A.S., Civitelli, L., Donini, P., Schramke, V., Geli, V., Ascenzioni, F., and Gilson, E. (2003). The number of vertebrate repeats can be regulated at yeast telomeres by Rap1-independent mechanisms. EMBO J 22, 1697-1706.

Broccoli, D., Smogorzewska, A., Chong, L., and de Lange, T. (1997). Human telomeres contain two distinct Myb-related proteins, TRF1 and TRF2. Nat Genet 17, 231-235.

Bryan, T.M. (2020). G-Quadruplexes at Telomeres: Friend or Foe? Molecules 25.

Buchman, A.R., Kimmerly, W.J., Rine, J., and Kornberg, R.D. (1988). Two DNA-binding factors recognize specific sequences at silencers, upstream activating sequences, autonomously replicating sequences, and telomeres in Saccharomyces cerevisiae. Mol Cell Biol 8, 210-225.

Cassani, C., Gobbini, E., Wang, W., Niu, H., Clerici, M., Sung, P., and Longhese, M.P. (2016). Tel1 and Rif2 Regulate MRX Functions in End-Tethering and Repair of DNA Double-Strand Breaks. PLoS Biol 14, e1002387.

Červenák, F., Juríková, K., Devillers, H., Kaffe, B., Khatib, A., Bonnell, E., Sopkovičová, M., Wellinger, R.J., Nosek, J., Tzfati, Y., et al. (2019). Identification of telomerase RNAs in 
species of the Yarrowia clade provides insights into the co-evolution of telomerase, telomeric repeats and telomere-binding proteins. Sci Rep 9, 13365.

Chang, M., Arneric, M., and Lingner, J. (2007). Telomerase repeat addition processivity is increased at critically short telomeres in a Tel1-dependent manner in Saccharomyces cerevisiae. Genes Dev 21, 2485-2494.

Cohn, M., McEachern, M.J., and Blackburn, E.H. (1998). Telomeric sequence diversity within the genus Saccharomyces. Curr Genet 33, 83-91.

Conrad, M.N., Wright, J.H., Wolf, A.J., and Zakian, V.A. (1990). RAP1 protein interacts with yeast telomeres in vivo: overproduction alters telomere structure and decreases chromosome stability. Cell 63, 739-750.

Cooper, J.P., Nimmo, E.R., Allshire, R.C., and Cech, T.R. (1997). Regulation of telomere length and function by a Myb-domain protein in fission yeast. Nature 385, 744-747.

Craven, R.J., and Petes, T.D. (1999). Dependence of the regulation of telomere length on the type of subtelomeric repeat in the yeast Saccharomyces cerevisiae. Genetics 152, 1531-1541.

Downey, M., Houlsworth, R., Maringele, L., Rollie, A., Brehme, M., Galicia, S., Guillard, S., Partington, M., Zubko, M.K., Krogan, N.J., et al. (2006). A genome-wide screen identifies the evolutionarily conserved KEOPS complex as a telomere regulator. Cell 124, 1155-1168.

Fang, G., and Cech, T.R. (1993). The beta subunit of Oxytricha telomere-binding protein promotes G-quartet formation by telomeric DNA. Cell 74, 875-885.

Förstemann, K., and Lingner, J. (2001). Molecular basis for telomere repeat divergence in budding yeast. Mol Cell Biol 21, 7277-7286.

Förstemann, K., Zaug, A.J., Cech, T.R., and Lingner, J. (2003). Yeast telomerase is specialized for C/A-rich RNA templates. Nucleic Acids Res 31, 1646-1655.

Gartenberg, M.R., and Smith, J.S. (2016). The Nuts and Bolts of Transcriptionally Silent Chromatin in Saccharomyces cerevisiae. Genetics 203, 1563-1599.

Garvik, B., Carson, M., and Hartwell, L. (1995). Single-stranded DNA arising at telomeres in cdc13 mutants may constitute a specific signal for the RAD9 checkpoint. Mol Cell Biol 15, 6128-6138.

Giraldo, R., and Rhodes, D. (1994). The yeast telomere-binding protein RAP1 binds to and promotes the formation of DNA quadruplexes in telomeric DNA. EMBO J 13, 2411-2420.

Gottschling, D.E., Aparicio, O.M., Billington, B.L., and Zakian, V.A. (1990). Position effect at $S$. cerevisiae telomeres: Reversible repression of Pol II transcription. Cell 63, 751-762.

Graf, M., Bonetti, D., Lockhart, A., Serhal, K., Kellner, V., Maicher, A., Jolivet, P., Teixeira, M.T., and Luke, B. (2017). Telomere Length Determines TERRA and R-Loop Regulation through the Cell Cycle. Cell 170, 72-85 e14.

Grandin, N., Damon, C., and Charbonneau, M. (2001). Ten1 functions in telomere end protection and length regulation in association with Stn1 and Cdc13. Embo J 20, 1173-1183. 
Grandin, N., Reed, S.I., and Charbonneau, M. (1997). Stn1, a new Saccharomyces cerevisiae protein, is implicated in telomere size regulation in association with Cdc13. Genes Dev 11, 512-527.

Gravel, S., Larrivee, M., Labrecque, P., and Wellinger, R.J. (1998). Yeast Ku as a regulator of chromosomal DNA end structure. Science 280, 741-744.

Guérin, T.M., Béneut, C., Barinova, N., López, V., Lazar-Stefanita, L., Deshayes, A., Thierry, A., Koszul, R., Dubrana, K., and Marcand, S. (2019). Condensin-Mediated Chromosome Folding and Internal Telomeres Drive Dicentric Severing by Cytokinesis. Mol Cell 75, 131-144 e133.

Guiducci, C., Cerone, M.A., and Bacchetti, S. (2001). Expression of mutant telomerase in immortal telomerase-negative human cells results in cell cycle deregulation, nuclear and chromosomal abnormalities and rapid loss of viability. Oncogene 20,714-725.

Hailemariam, S., De Bona, P., Galletto, R., Hohl, M., Petrini, J.H., and Burgers, P.M. (2019). The telomere-binding protein Rif2 and ATP-bound Rad50 have opposing roles in the activation of yeast Tel1(ATM) kinase. J Biol Chem 294, 18846-18852.

Hardy, C.F., Sussel, L., and Shore, D. (1992). A RAP1-interacting protein involved in transcriptional silencing and telomere length regulation. Genes Dev 6, 801-814.

Hass, E.P., and Zappulla, D.C. (2015). The Ku subunit of telomerase binds Sir4 to recruit telomerase to lengthen telomeres in $S$. cerevisiae. eLife 4.

Hirano, Y., Fukunaga, K., and Sugimoto, K. (2009). Rif1 and Rif2 inhibit localization of Tel1 to DNA ends. Mol Cell 33, 312-322.

Iglesias, N., Redon, S., Pfeiffer, V., Dees, M., Lingner, J., and Luke, B. (2011). Subtelomeric repetitive elements determine TERRA regulation by Rap1/Rif and Rap1/Sir complexes in yeast. EMBO Rep 12, 587-593.

Jain, D., and Cooper, J.P. (2010). Telomeric strategies: means to an end. Annu Rev Genet 44, 243-269.

Jansson, L.I., Hentschel, J., Parks, J.W., Chang, T.R., Lu, C., Baral, R., Bagshaw, C.R., and Stone, M.D. (2019). Telomere DNA G-quadruplex folding within actively extending human telomerase. Proc Natl Acad Sci U S A 116, 9350-9359.

Kim, M.M., Rivera, M.A., Botchkina, I.L., Shalaby, R., Thor, A.D., and Blackburn, E.H. (2001). A low threshold level of expression of mutant-template telomerase RNA inhibits human tumor cell proliferation. Proc Natl Acad Sci U S A 98, 7982-7987.

Krauskopf, A., and Blackburn, E.H. (1996). Control of telomere growth by interactions of RAP1 with the most distal telomeric repeats. Nature 383, 354-357.

Kyrion, G., Liu, K., Liu, C., and Lustig, A.J. (1993). RAP1 and telomere structure regulate telomere position effects in Saccharomyces cerevisiae. Genes Dev 7, 1146-1159.

Levy, D.L., and Blackburn, E.H. (2004). Counting of Rif1p and Rif2p on Saccharomyces cerevisiae telomeres regulates telomere length. Mol Cell Biol 24, 10857-10867. 
Lieb, J.D., Liu, X., Botstein, D., and Brown, P.O. (2001). Promoter-specific binding of Rap1 revealed by genome-wide maps of protein-DNA association. Nat Genet 28, 327-334.

Lin, J., Smith, D.L., and Blackburn, E.H. (2004). Mutant telomere sequences lead to impaired chromosome separation and a unique checkpoint response. Mol Biol Cell 15, 1623-1634.

Lin, J.J., and Zakian, V.A. (1996). The Saccharomyces CDC13 protein is a single-strand TG 3 telomeric DNA-binding protein in vitro that affects telomere behavior in vivo. Proc Natl Acad Sci U S A 93, 13760-13765.

Lingner, J., Hughes, T.R., Shevchenko, A., Mann, M., Lundblad, V., and Cech, T.R. (1997). Reverse transcriptase motifs in the catalytic subunit of telomerase. Science 276, 561-567.

Loayza, D., Parsons, H., Donigian, J., Hoke, K., and de Lange, T. (2004). DNA binding features of human POT1: a nonamer 5'-TAGGGTTAG-3' minimal binding site, sequence specificity, and internal binding to multimeric sites. J Biol Chem 279, 13241-13248.

Lundblad, V., and Blackburn, E.H. (1993). An alternative pathway for yeast telomere maintenance rescues est1- senescence. Cell 73, 347-360.

Lundblad, V., and Struhl, K. (2010). Yeast. Current Protocols in Molecular Biology 92.

Lustig, A.J., Kurtz, S., and Shore, D. (1990). Involvement of the silencer and UAS binding protein RAP1 in regulation of telomere length. Science 250, 549-553.

Makovets, S., Herskowitz, I., and Blackburn, E.H. (2004). Anatomy and dynamics of DNA replication fork movement in yeast telomeric regions. Mol Cell Biol 24, 4019-4031.

Marcand, S., Gilson, E., and Shore, D. (1997). A protein-counting mechanism for telomere length regulation in yeast. Science 275 , 986-990.

Marcand, S., Pardo, B., Gratias, A., Cahun, S., and Callebaut, I. (2008). Multiple pathways inhibit NHEJ at telomeres. Genes Dev 22, 1153-1158.

Marušić, L., Anton, M., Tidy, A., Wang, P., Villeponteau, B., and Bacchetti, S. (1997). Reprogramming of telomerase by expression of mutant telomerase RNA template in human cells leads to altered telomeres that correlate with reduced cell viability. Mol Cell Biol 17, 6394-6401.

Moretti, P., Freeman, K., Coodly, L., and Shore, D. (1994). Evidence that a complex of SIR proteins interacts with the silencer and telomere-binding protein RAP1. Genes Dev 8, 22572269.

Negrini, S., Ribaud, V., Bianchi, A., and Shore, D. (2007). DNA breaks are masked by multiple Rap1 binding in yeast: Implications for telomere capping and telomerase regulation. Genes Dev 21, 292-302.

Nugent, C.I., Hughes, T.R., Lue, N.F., and Lundblad, V. (1996). Cdc13p: a single-strand telomeric DNA-binding protein with a dual role in yeast telomere maintenance. Science 274, 249-252. 
Oh, J., and Symington, L.S. (2018). Role of the Mre11 Complex in Preserving Genome Integrity. Genes (Basel) 9.

Paeschke, K., Bochman, M.L., Garcia, P.D., Cejka, P., Friedman, K.L., Kowalczykowski, S.C., and Zakian, V.A. (2013). Pif1 family helicases suppress genome instability at Gquadruplex motifs. Nature 497, 458-462.

Paeschke, K., Juranek, S., Simonsson, T., Hempel, A., Rhodes, D., and Lipps, H.J. (2008). Telomerase recruitment by the telomere end binding protein-beta facilitates G-quadruplex DNA unfolding in ciliates. Nat Struct Mol Biol 15, 598-604.

Paeschke, K., Simonsson, T., Postberg, J., Rhodes, D., and Lipps, H.J. (2005). Telomere endbinding proteins control the formation of G-quadruplex DNA structures in vivo. Nat Struct Mol Biol 12, 847-854.

Pardo, B., and Marcand, S. (2005). Rap1 prevents telomere fusions by nonhomologous end joining. EMBO J 24, 3117-3127.

Postberg, J., Tsytlonok, M., Sparvoli, D., Rhodes, D., and Lipps, H.J. (2012). A telomeraseassociated RecQ protein-like helicase resolves telomeric G-quadruplex structures during replication. Gene 497, 147-154.

Prescott, J.C., and Blackburn, E.H. (2000). Telomerase RNA template mutations reveal sequence-specific requirements for the activation and repression of telomerase action at telomeres. Mol Cell Biol 20, 2941-2948.

Rhodes, D., and Lipps, H.J. (2015). G-quadruplexes and their regulatory roles in biology. Nucleic Acids Res 43, 8627-8637.

Rossmann, M.P., Luo, W., Tsaponina, O., Chabes, A., and Stillman, B. (2011). A common telomeric gene silencing assay is affected by nucleotide metabolism. Mol Cell 42, 127-136.

Sabourin, M., Tuzon, C.T., and Zakian, V.A. (2007). Telomerase and Tel1p Preferentially Associate with Short Telomeres in S. cerevisiae. Mol Cell.

Sandell, L.L., and Zakian, V.A. (1993). Loss of a yeast telomere: arrest, recovery, and chromosome loss. Cell 75, 729-739.

Shampay, J., Szostak, J.W., and Blackburn, E.H. (1984). DNA sequences of telomeres maintained in yeast. Nature 310, 154-157.

Sherman, F. (2002). Getting started with yeast. Methods Enzymol 350, 3-41.

Shore, D., and Nasmyth, K. (1987). Purification and cloning of a DNA binding protein from yeast that binds to both silencer and activator elements. Cell 51, 721-732.

Smith, J.S., Chen, Q., Yatsunyk, L.A., Nicoludis, J.M., Garcia, M.S., Kranaster, R., Balasubramanian, S., Monchaud, D., Teulade-Fichou, M.P., Abramowitz, L., et al. (2011). Rudimentary G-quadruplex-based telomere capping in Saccharomyces cerevisiae. Nat Struct Mol Biol 18, 478-485. 
Steinberg-Neifach, O., and Lue, N.F. (2015). Telomere DNA recognition in Saccharomycotina yeast: potential lessons for the co-evolution of ssDNA and dsDNAbinding proteins and their target sites. Front Genet 6, 162.

Stinus, S., Paeschke, K., and Chang, M. (2017). Telomerase regulation by the Pif1 helicase: a length-dependent effect? Curr Genet.

Strecker, J., Stinus, S., Caballero, M.P., Szilard, R.K., Chang, M., and Durocher, D. (2017). A sharp Pif1-dependent threshold separates DNA double-strand breaks from critically short telomeres. eLife 6, e23783.

Symington, L.S., Rothstein, R., and Lisby, M. (2014). Mechanisms and Regulation of Mitotic Recombination in Saccharomyces cerevisiae. Genetics 198, 795-835.

Teixeira, M.T., Arneric, M., Sperisen, P., and Lingner, J. (2004). Telomere length homeostasis is achieved via a switch between telomerase- extendible and -nonextendible states. Cell 117, 323-335.

Traczyk, A., Liew, C.W., Gill, D.J., and Rhodes, D. (2020). Structural basis of G-quadruplex DNA recognition by the yeast telomeric protein Rap1. Nucleic Acids Res 48, 4562-4571.

van Mourik, P.M., de Jong, J., Agpalo, D., Claussin, C., Rothstein, R., and Chang, M. (2016). Recombination-Mediated Telomere Maintenance in Saccharomyces cerevisiae Is Not Dependent on the Shu Complex. PLOS ONE 11, e0151314.

van Mourik, P.M., de Jong, J., Sharma, S., Kavsek, A., Chabes, A., and Chang, M. (2018). Upregulation of dNTP Levels After Telomerase Inactivation Influences TelomeraseIndependent Telomere Maintenance Pathway Choice in Saccharomyces cerevisiae. G3 (Bethesda) 8, 2551-2558.

Varshney, D., Spiegel, J., Zyner, K., Tannahill, D., and Balasubramanian, S. (2020). The regulation and functions of DNA and RNA G-quadruplexes. Nat Rev Mol Cell Biol 21, 459474.

Venczel, E.A., and Sen, D. (1993). Parallel and antiparallel G-DNA structures from a complex telomeric sequence. Biochemistry 32, 6220-6228.

Vodenicharov, M.D., Laterreur, N., and Wellinger, R.J. (2010). Telomere capping in nondividing yeast cells requires Yku and Rap1. EMBO J 29, 3007-3019.

Wahlin, J., and Cohn, M. (2000). Saccharomyces cerevisiae RAP1 binds to telomeric sequences with spatial flexibility. Nucleic Acids Res 28, 2292-2301.

Wilson, T.E., Grawunder, U., and Lieber, M.R. (1997). Yeast DNA ligase IV mediates nonhomologous DNA end joining. Nature 388, 495-498.

Wotton, D., and Shore, D. (1997). A novel Rap1p-interacting factor, Rif2p, cooperates with Rif1p to regulate telomere length in Saccharomyces cerevisiae. Genes Dev 11, 748-760. 
bioRxiv preprint doi: https://doi.org/10.1101/2020.12.30.424824; this version posted December 30, 2020. The copyright holder for this preprint (which was not certified by peer review) is the author/funder, who has granted bioRxiv a license to display the preprint in Figure 1 perpetuity. It is made available under aCC-BY-NC-ND 4.0 International license.

A

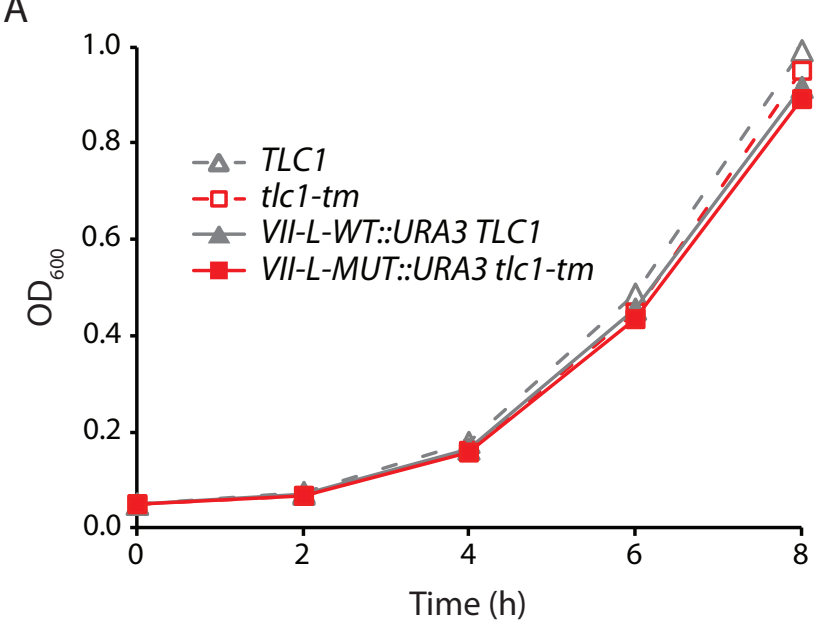

C

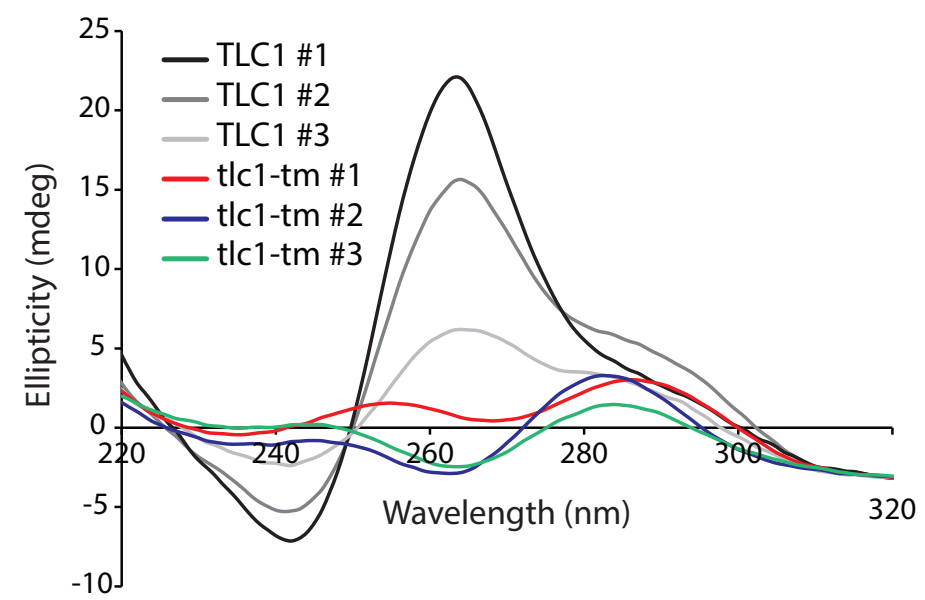

B

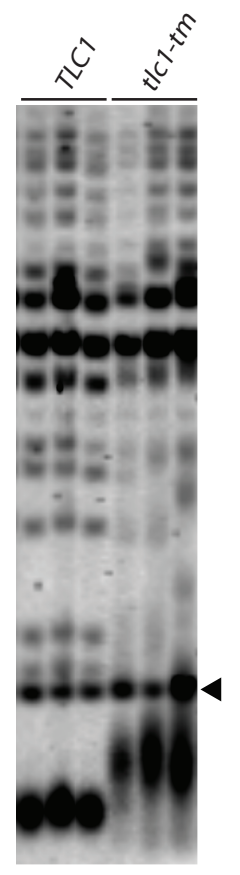

TLC1 oligo \#1 (32 nt)

TLC1 oligo \#2 (41 nt)

TLC1 oligo \#3 (42 nt)

tlc1-tm oligo \#1 (33 nt)

tlc1-tm oligo \#2 (36 nt) TGTGGTGTGGAtTtGGTGTGTGTGGTGTGTGGTGTG

tlc1-tm oligo \#3 (42 nt) TGGTGTGGTGTGTGGTGTGTGGTGTGTGGATTTGGTGTGGTG
D

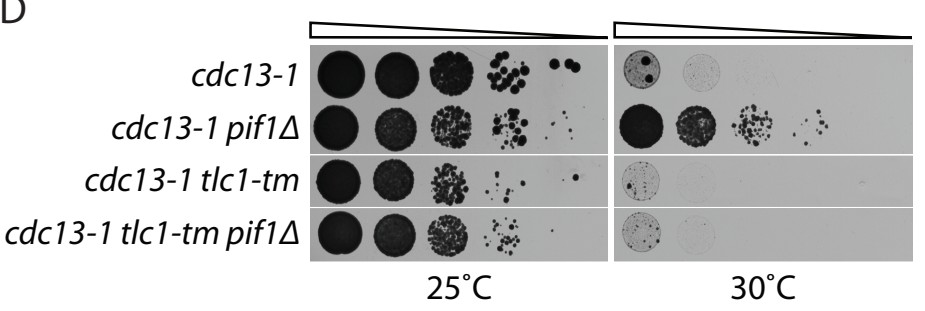

$\mathrm{E}$

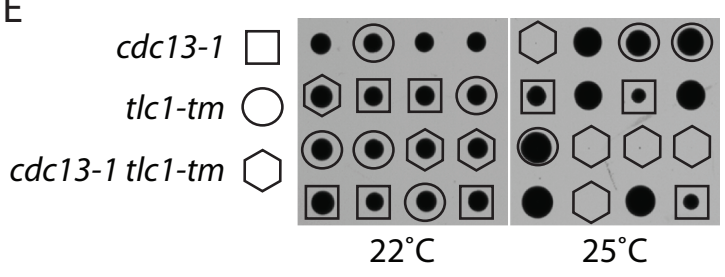

\section{Figure 1. t/c1-tm mutant telomere sequences are impaired in forming G-quadruplexes}

(A) Exponentially growing cells of the indicated genotypes were diluted to an $\mathrm{OD}_{600}$ of 0.05 and monitored for $8 \mathrm{~h}$. Three clones of each genotype were followed, and the average of the measurements at each time point is plotted.

(B) Telomere Southern blot analysis of TLC1 and t/c1-tm cells (three clonal isolates per genotype). Black arrowhead indicates a 1.8 kb DNA fragment generated from the BsmAl-digestion of plasmid pYt103 (Shampay et al., 1984). The major terminal restriction fragment is below the $1.8 \mathrm{~kb}$ control band.

(C) CD spectra of oligonucleotides with either wild-type or t/c1-tm telomeric sequence. Average of three measurements is plotted.

(D) Tenfold serial dilutions of strains with the indicated genotypes were spotted on YPD plates and grown at $25^{\circ} \mathrm{C}$ or $30^{\circ} \mathrm{C}$.

(E) A cdc13-1/CDC13 t/c1-tm/TLC1 diploid strain was sporulated and the resulting tetrads were dissected on YPD plates, which were incubated at $22^{\circ} \mathrm{C}$ or $25^{\circ} \mathrm{C}$. Each column of colonies arose from a single tetrad. 
bioRxiv preprint doi: https://doi.org/10.1101/2020.12.30.424824; this version posted December 30, 2020. The copyright holder for this

preprint (which was not certified by peer review) is the author/funder, who has granted bioRxiv a license to display the preprint in

\section{Figure 2} perpetuity. It is made available under aCC-BY-NC-ND 4.0 International license.

A
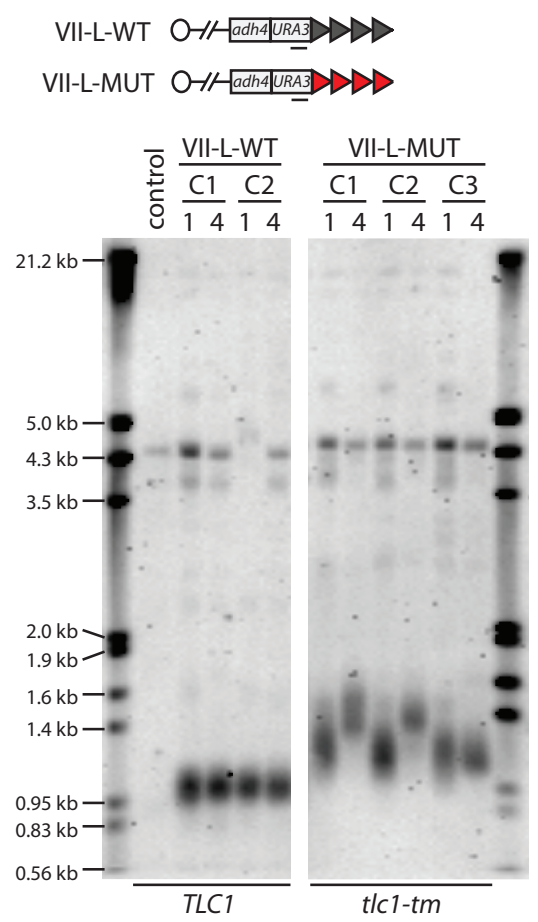

D

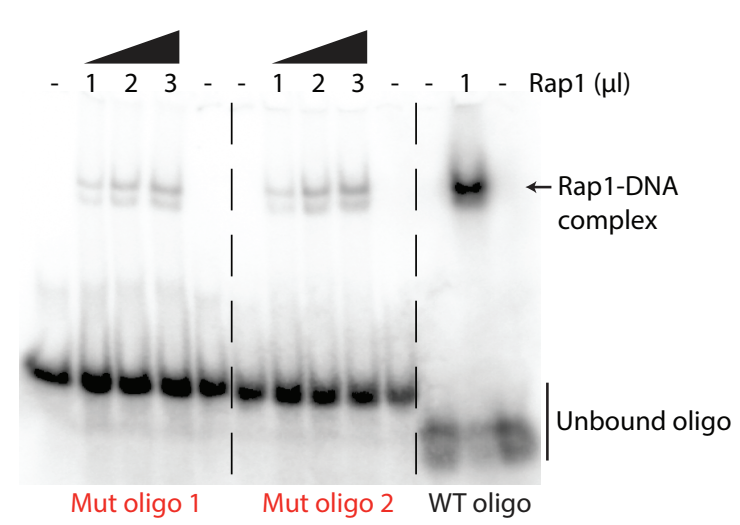

B

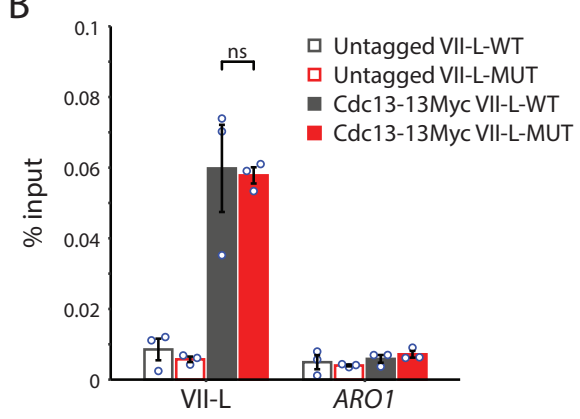

C

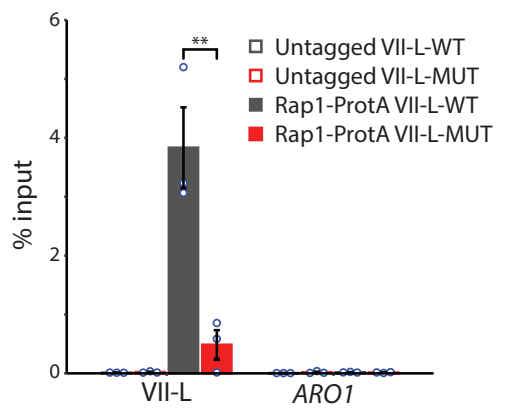

$\mathrm{E}$

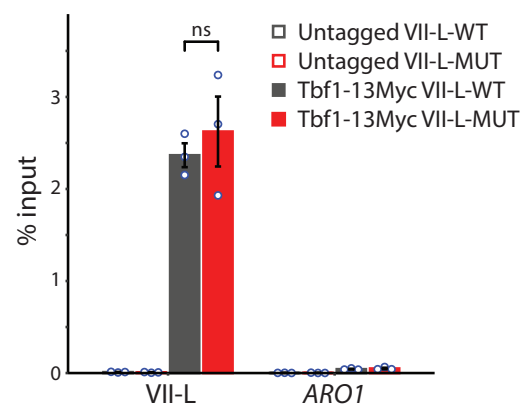

\section{Figure 2. Rap1 binds poorly to t/c1-tm telomeres}

(A) Southern blot analysis of the artificial VII-L telomere, with either wild-type or t/c1-tm mutant sequence, using a probe to the adjacent URA3 gene. Multiple clones were examined, with each clone propagated for 1 to 4 passages. A wild-type strain (lacking the artificial VII-L telomere) was used as a control.

(B, C, E) ChIP-qPCR analysis of the association of (B) Myc-tagged Cdc13, (C) Protein A-tagged Rap1, and (E) Myc-tagged Tbf1 to the VII-L telomere or to the non-telomeric ARO1 locus. Untagged wild-type and t/c1-tm strains were used as controls. The mean percentage of input $+/$ - SEM is shown $\left(n=3,{ }^{* *} p<0.01\right)$.

(D) EMSA of Rap1 protein incubated with radiolabeled oligonucleotides with either wild-type or t/c1-tm mutant telomeric sequence. 
bioRxiv preprint doi: https://doi.org/10.1101/2020.12.30.424824; this version posted December 30, 2020. The copyright holder for this preprint (which was not certified by peer review) is the author/funder, who has granted bioRxiv a license to display the preprint in

\section{Figure 3} perpetuity. It is made available under aCC-BY-NC-ND 4.0 International license.

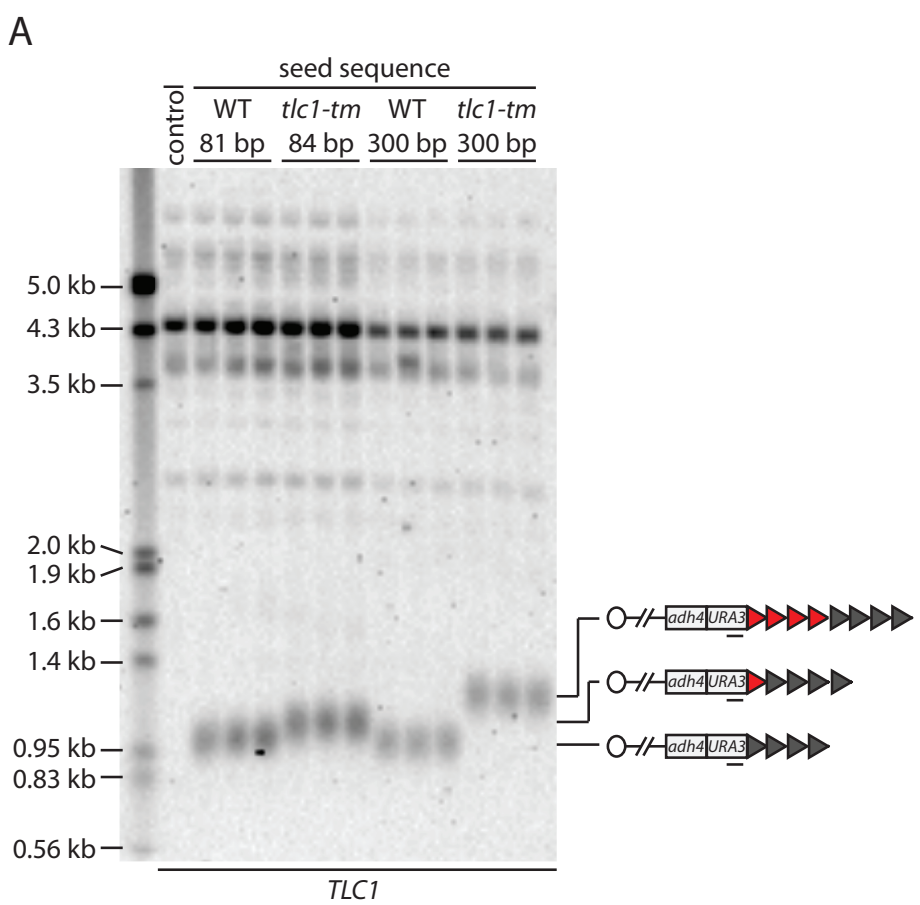

B

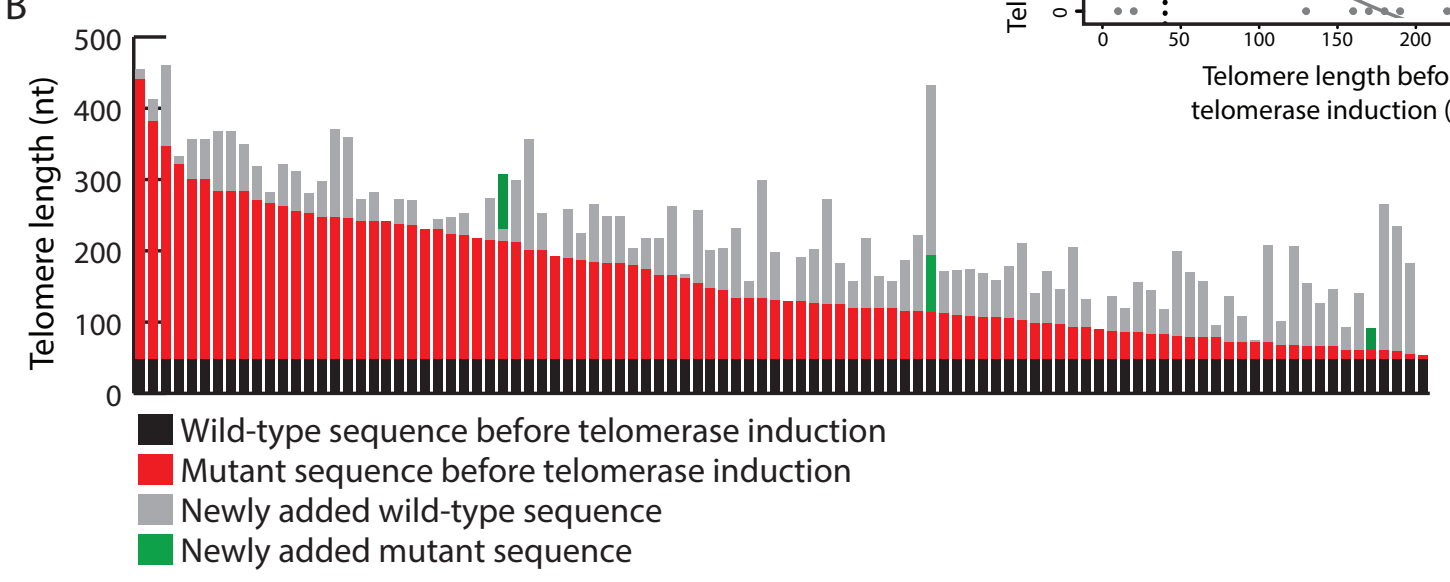

C

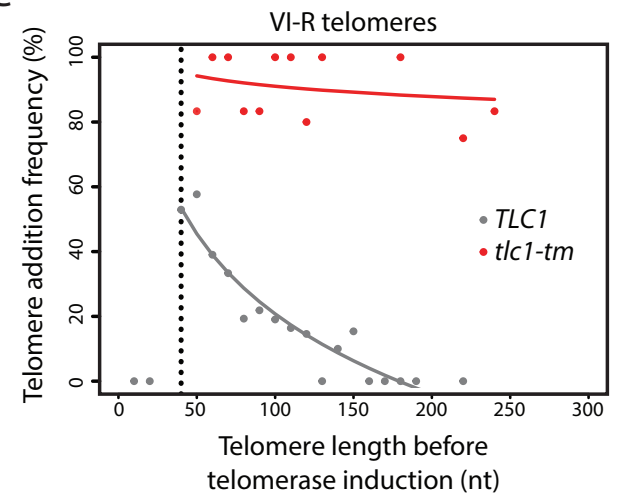

Figure 3. Telomere length regulation is disrupted in t/c1-tm cells

(A) Southern blot analysis of the artificial VII-L telomere using a probe to the adjacent URA3 gene. The telomere was seeded with either wild-type or t/c1-tm mutant sequence of the indicated lengths in a strain expressing wild-type TLC1. Multiple clones of each strain were examined. A wild-type strain (lacking the artificial VII-L telomere) was used as a control.

(B) In vivo extension of $t / c 1-t m$ telomeres was examined using the iSTEX assay. Telomere VI-R was amplified and sequenced after the induction of wild-type telomerase. Each bar represents an individual telomere. The black and red portions of each bar represent wild-type and t/c 1-tm sequence, respectively, that is identical in sequence and thus present before telomerase induction. Sequence that is divergent from the black and red sequence is shown in grey and green. Grey represents newly added wild-type sequence after the induction of telomerase. Green represents divergent $t / c 1$-tm sequence, most likely a result of homologous recombination. Telomeres are sorted based on the length of the undiverged (black plus red) sequence.

(C) Telomere VI-R sequences obtained from the iSTEX analysis in B were binned into groups of $10 \mathrm{nt}$ in size according to telomere length before telomerase induction. iSTEX data for the extension of wild-type telomeres were taken from previous studies (Strecker et al., 2017; Stinus et al., 2017) and included for comparison. Groups containing less than four telomeres were excluded from this analysis. Frequency of extension and average telomere length before telomerase induction were calculated and plotted for each group. Logarithmic regression curves for each data set were also included in the plot. Telomeres shorter than $40 \mathrm{nt}$ before telomerase induction, which are not efficiently recognized and extended by telomerase (Strecker et al., 2017), were removed from the regression analysis. 
bioRxiv preprint doi: https://doi.org/10.1101/2020.12.30.424824; this version posted December 30, 2020. The copyright holder for this

preprint (which was not certified by peer review) is the author/funder, who has granted bioRxiv a license to display the preprint in

\section{Figure 4} perpetuity. It is made available under aCC-BY-NC-ND 4.0 International license.

A
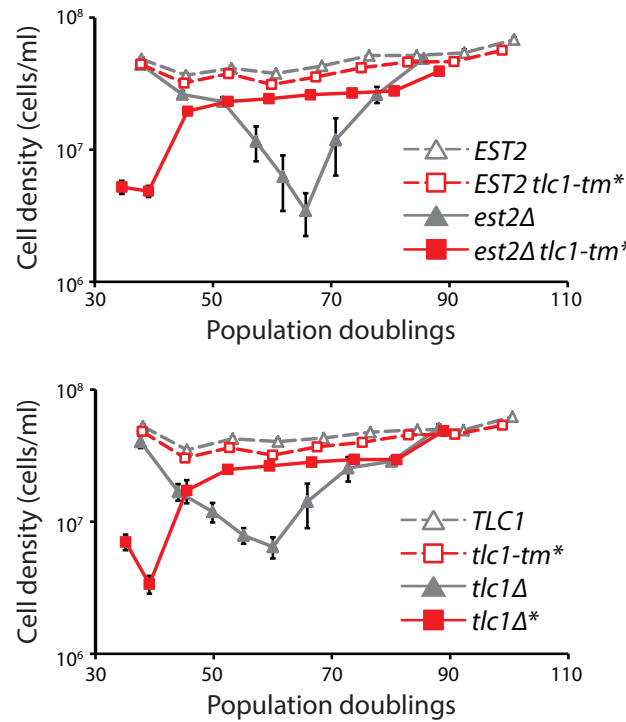

B

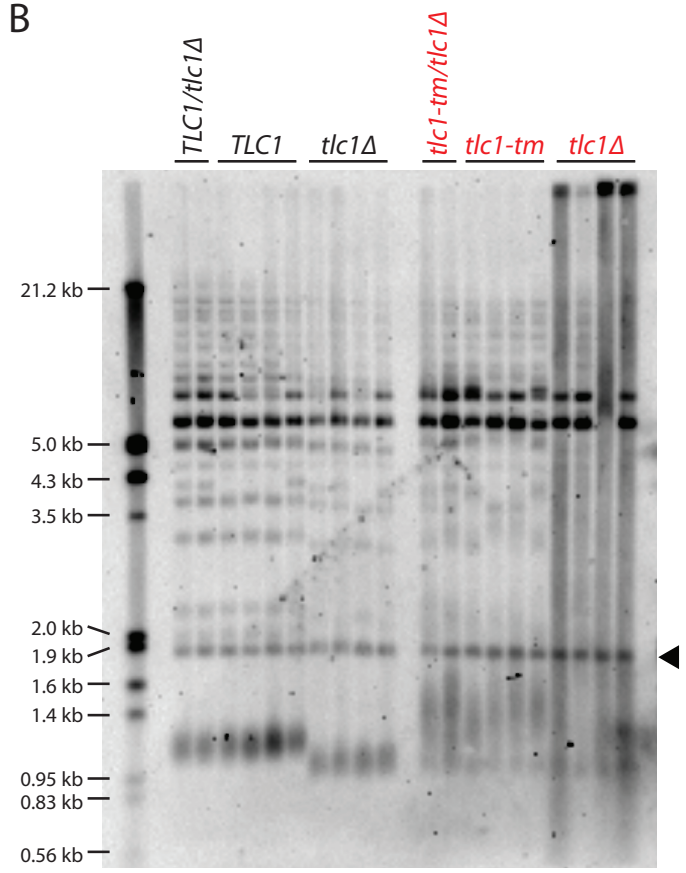

Figure 4. Fast degradation of tIc1-tm telomeres in the absence of telomerase

(A) Senescence rates were measured by serial passaging of strains of the indicated genotypes, derived from the sporulation of est2 $\triangle / E S T 2$ and est2 $\triangle / E S T 2$ t/c1-tm/t/c1-tm diploids (top panel) or $t / c 1 \Delta / T L C 1$ and $t / c 1 \Delta / t / c 1-t m$ diploids (bottom panel). Cell density was measured every $24 \mathrm{~h}$, followed by dilution to $1 \times 10^{5} \mathrm{cell} / \mathrm{ml}$. Mean $+/$ - SEM of four independent isolates per genotype is plotted.

(B) Telomere Southern blot analysis of samples obtained at the first time point of the senescence assays in A. Black arrowhead indicates the $1.8 \mathrm{~kb}$ telomere sequence-containing fragment loaded as control, as in Figure 1B. 
bioRxiv preprint doi: https://doi.org/10.1101/2020.12.30.424824; this version posted December 30, 2020. The copyright holder for this

preprint (which was not certified by peer review) is the author/funder, who has granted bioRxiv a license to display the preprint in

Figure 5 perpetuity. It is made available under aCC-BY-NC-ND 4.0 International license.

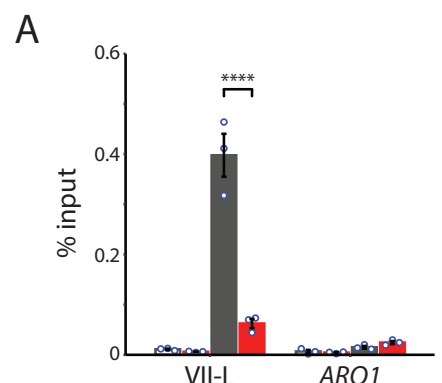

- Untagged VII-L-WT

ㄴ Untagged VII-L-MUT

- Rif1-13Myc VII-L-WT

Rif1-13Myc VII-L-MUT

B

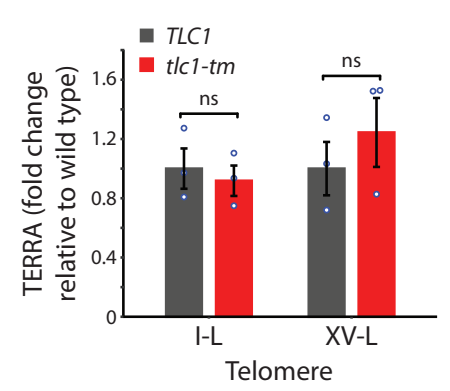

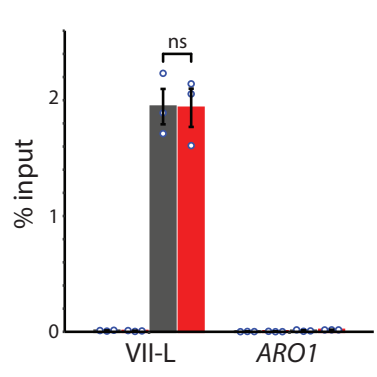

口 Untagged VII-L-WT

Untagged VII-L-MUT

- Rif2-13Myc VII-L-WT

- Rif2-13Myc VII-L-MUT

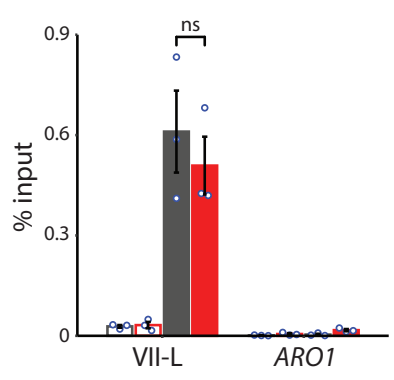

口 Untagged VII-L-WT

ㄴ Untagged VII-L-MUT

- Sir3-ProtA VII-L-WT

- Sir3-ProtA VII-L-MUT

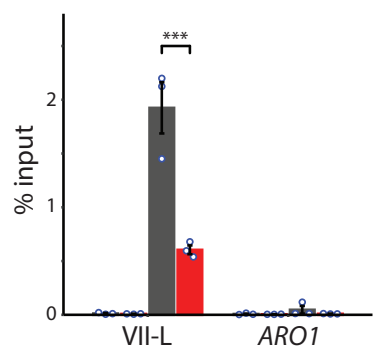

$\square$ Untagged VII-L-WT

$\square$ Untagged VII-L-MUT

- Sir4-13Myc VII-L-WT
C

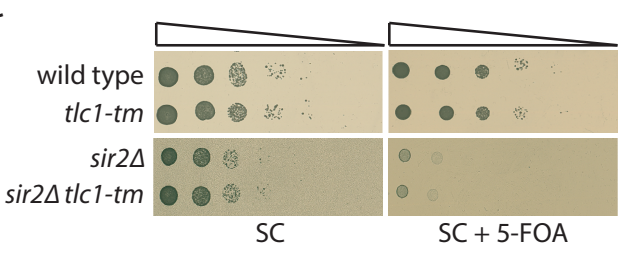

D

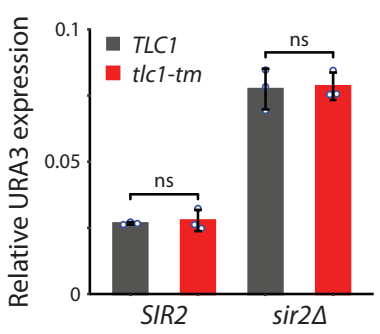

Figure 5. Recruitment of Rif1 and Sir4, but not Rif2 nor Sir3, is significantly reduced at t/c1-tm telomeres

(A) ChIP-qPCR analysis of the association of Myc-tagged Rif1, Rif2, Sir4, and Protein A-tagged Sir3 to the VII-L telomere or to the non-telomeric $A R O 1$ locus. Untagged wild-type and t/c1-tm strains were used as controls.

(B) Total RNA was reverse transcribed and TERRA from specific telomeres (I-L and XV-L) was analyzed by qPCR. TERRA values were normalized to $A C T 1$ levels, and to the respective wild type ( $T L C 1)$.

(C) Tenfold serial dilutions of strains with the indicated genotypes were spotted on SC plates without or with 5-FOA.

(D) The expression of the subtelomerically integrated URA3 gene was measured in the indicated yeast strains by RT-qPCR.

All data (except $C)$ are shown as mean $+/-\operatorname{SEM}\left(n=3,{ }^{* * *} p<10^{-3}, * * * * p<10^{-4}\right)$. 
bioRxiv preprint doi: https://doi.org/10.1101/2020.12.30.424824; this version posted December 30, 2020. The copyright holder for this

preprint (which was not certified by peer review) is the author/funder, who has granted bioRxiv a license to display the preprint in

Figure 6 perpetuity. It is made available under aCC-BY-NC-ND 4.0 International license.

A

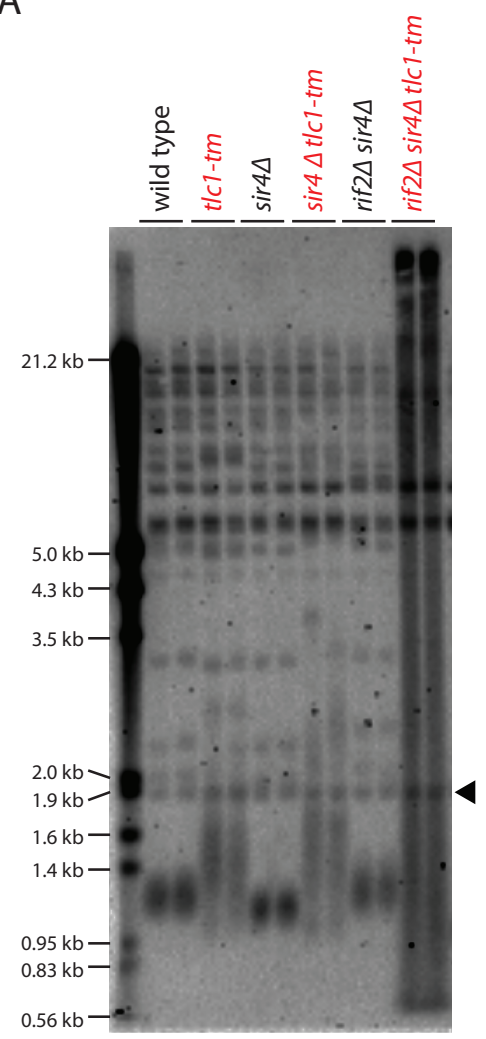

B

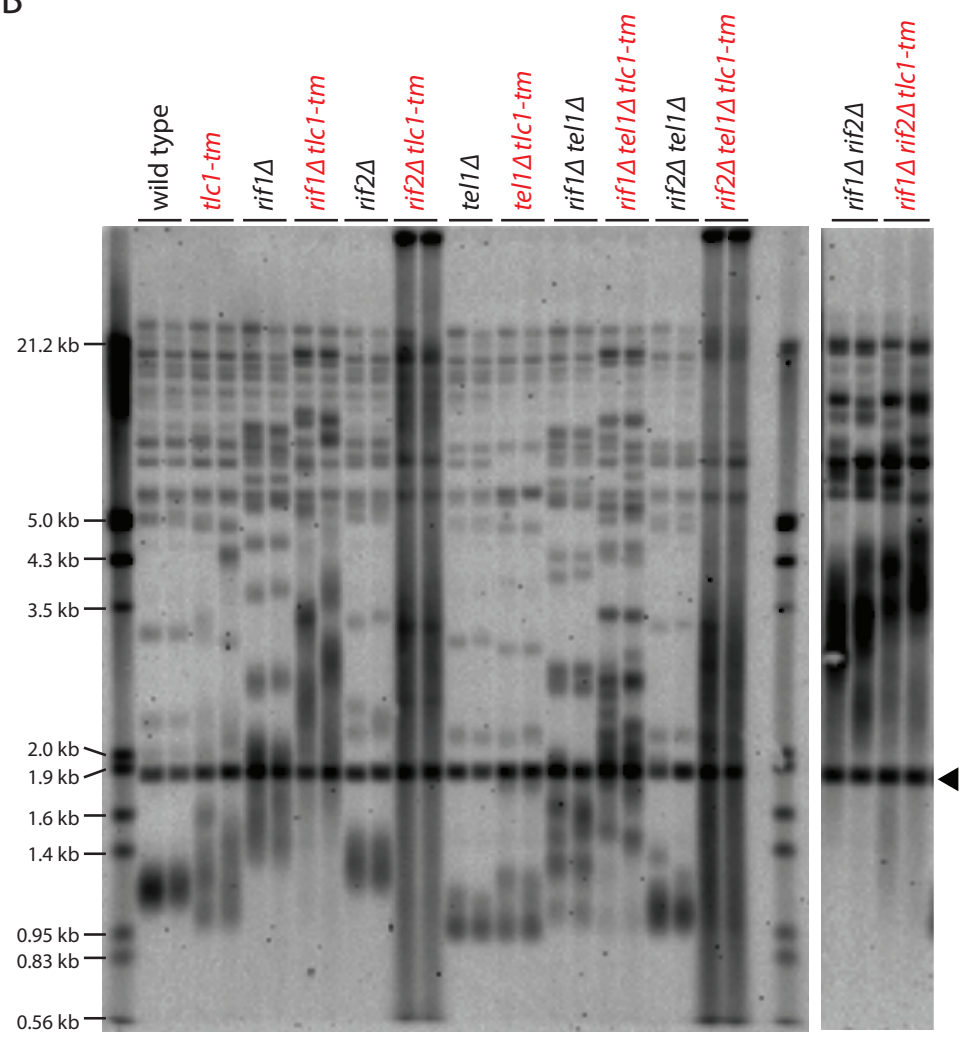

C

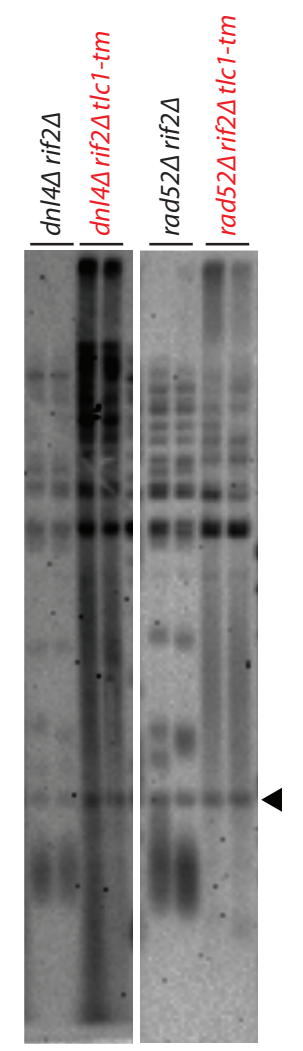

D
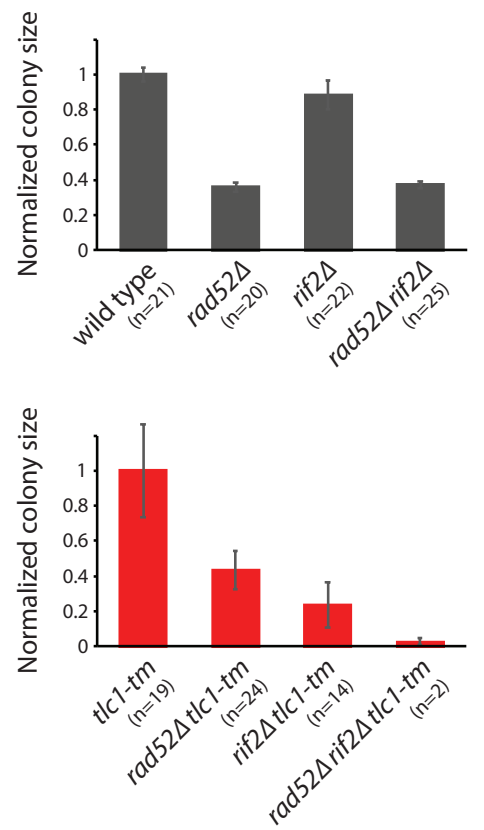

$\mathrm{E}$

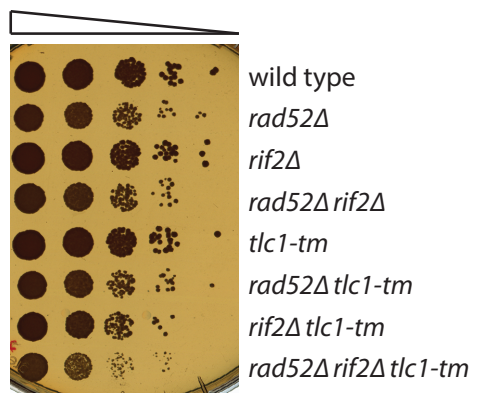

Figure 6. Rif2 prevents degradation of t/c1-tm telomeres

(A-C) Telomere Southern blot analysis of strains of the indicated genotypes. Black arrowhead indicates the $1.8 \mathrm{~kb}$ telomere sequence-containing fragment loaded as control, as in Figure 1B.

(D) Colony sizes of haploid meiotic progeny derived from the sporulation of rad52L/RAD52 rif2L/RIF2 and rad52L/RAD52 rif2L/RIF2 $\mathrm{t} / \mathrm{c} 1-\mathrm{tm} / \mathrm{t} / \mathrm{c} 1-\mathrm{tm}$ diploid strains were measured and normalized to wild-type (top panel) or t/c1-tm (bottom panel). The number of colonies analyzed is indicated in parenthesis. Error bars show SEM.

(E) Tenfold serial dilutions of strains with the indicated genotypes were spotted on YPD plates and grown at $30^{\circ} \mathrm{C}$. 
bioRxiv preprint doi: https://doi.org/10.1101/2020.12.30.424824; this version posted December 30, 2020. The copyright holder for this

preprint (which was not certified by peer review) is the author/funder, who has granted bioRxiv a license to display the preprint in

Figure 7 perpetuity. It is made available under aCC-BY-NC-ND 4.0 International license.

A

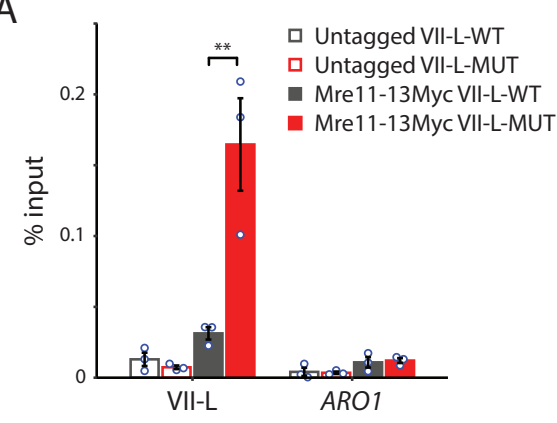

C

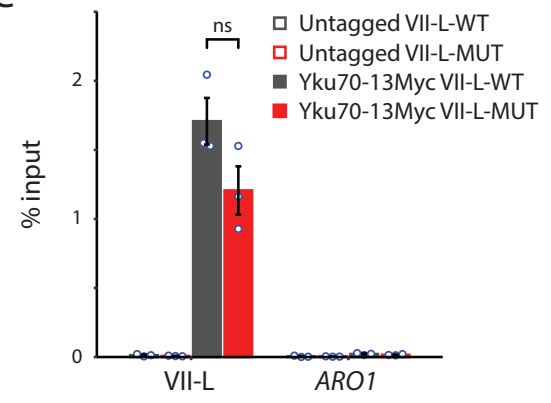

D
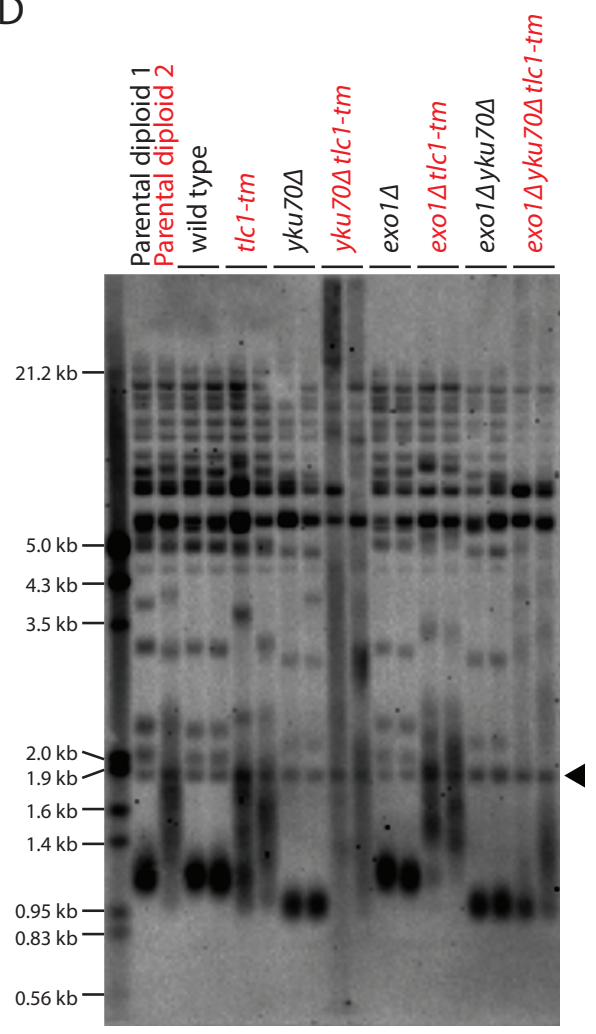

B

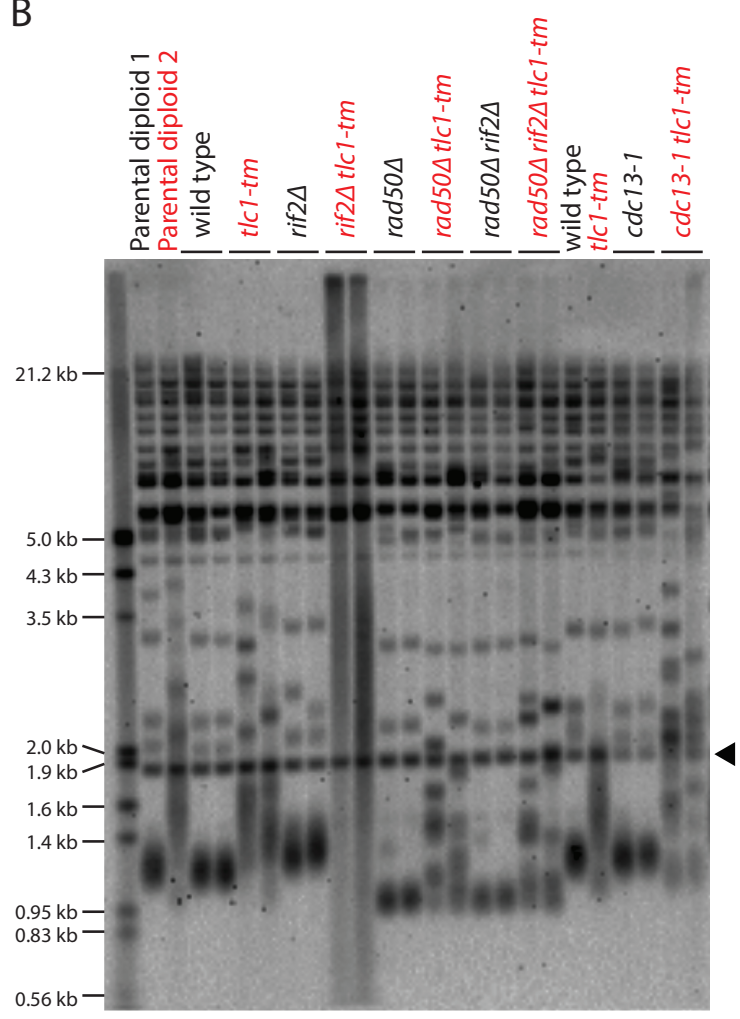

E
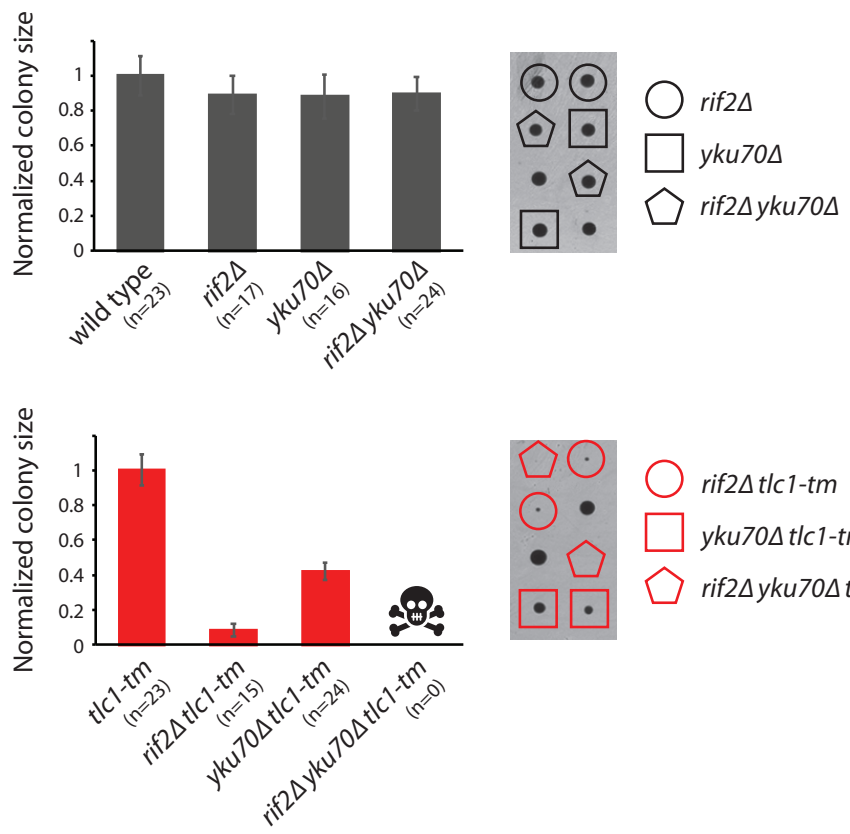

rif2 $\Delta$ tcc1-tm

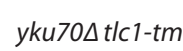

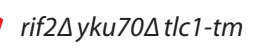

F

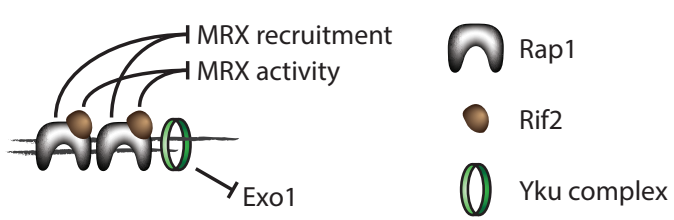


bioRxiv preprint doi: https://doi.org/10.1101/2020.12.30.424824; this version posted December 30, 2020. The copyright holder for this

preprint (which was not certified by peer review) is the author/funder, who has granted bioRxiv a license to display the preprint in perpetuity. It is made available under aCC-BY-NC-ND 4.0 International license.

Figure 7. Rif2 protects t/c1-tm telomeres by inhibiting the MRX complex and acts in parallel with the Yku complex (A\&C) ChIP-qPCR analysis of the association of Myc-tagged Mre11 and Yku70 to the VII-L telomere or to the non-telomeric ARO1 locus. Untagged wild-type and t/c1-tm strains were used as controls. The mean percentage of input $+/-\mathrm{SEM}$ is shown ( $\mathrm{n}=3$, *** $\mathrm{p}<0.01)$.

(B\&D) Telomere Southern blot analysis of strains of the indicated genotypes. Black arrowhead indicates the $1.8 \mathrm{~kb}$ telomere sequence-containing fragment loaded as control, as in Figure 1B. (B) Parental diploid 1 is rad50L/RAD50 rif2 $/ R I F 2 ;$ parental diploid 2 is rad50 $/ R A D 50$ rif2 $/ R$ RIF2 $\mathrm{tlc} 1-\mathrm{tm} / \mathrm{t} / \mathrm{c} 1-\mathrm{tm}$. The last six lanes are derived from cells grown at $22^{\circ} \mathrm{C}$. (D) Parental diploid 1 is

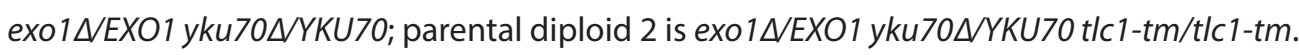

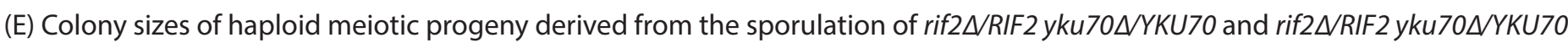
t/c1-tm/t/c1-tm diploid strains were measured and normalized to wild-type (top panel) or t/c1-tm (bottom panel). The number of colonies analyzed is indicated in parenthesis. Error bars show SEM. Representative images of dissected tetrads are shown on the right. Each column of colonies arose from a single tetrad.

(F) A model to illustrate how Rap1, Rif2, and the Yku complex work in concert to prevent telomere degradation. 